\author{
ANNA CHROBAK \\ Uniwersytet Pedagogiczny w Krakowie, Polska \\ Pedagogical University of Krakow, Poland
}

\title{
Przegląd metod waloryzacii obiektów przyrody nieożywionej wykorzystywanych w geoturystyce
}

\section{Review of the assessment methods of abiotic nature sites used in geotourism}

\begin{abstract}
Streszczenie: Niniejszy artykuł ma charakter przeglądowy i jego celem jest analiza i ocena metod waloryzacji geostanowisk. Metody te są przedmiotem wielu artykułów naukowych. Do niniejszego artykułu zostało wybranych 60 różnorodnych metod waloryzacji, które są: 1) metodami autorskimi; 2) metodami wcześniej opisanymi w literaturze; 3) modyfikacjami jednej lub kilku wcześniejszych metod; 4) kompilacjami różnych metod lub 5) metodami bez ściśle zdefiniowanych kryteriów. Wszystkie te metody łączy fakt, iż należą one do metod bonitacji punktowej, a różni je liczba kryteriów, dokładność opisu tych kryteriów i zastosowana skala punktowa. Do najczęściej stosowanych grup kryteriów, wg których przeprowadzana jest waloryzacja geostanowisk, należą: kryteria naukowe, potencjał użytkowania wraz z kryteriami turystycznymi oraz kryteria dodatkowe (m.in. kulturowe i estetyczne). Wszystkie przedstawione do tej pory w literaturze metody waloryzacji są metodami subiektywnymi, a wynik waloryzacji w znaczącym stopniu zależy tylko od wiedzy i doświadczenia eksperta, który daną waloryzację przeprowadza. Autorka niniejszego artykułu proponuje zastosowanie metody triangulacji eksperckiej, aby zmniejszyć subiektywność otrzymywanych w wyniku waloryzacji wyników.
\end{abstract}

\begin{abstract}
The article is a review and its purpose is to analyse and evaluate the valorisation methods of geosites. These methods are the subject of numerous scientific articles. For this article, selected were sixty different assessment methods which are 1 / original methods; 2 / methods previously described in the literature; 3 / modifications of one or more previous methods; 4 / compilations of various methods; or 5 / methods without strictly defined criteria. What all these methods have in common is the fact that they belong to the scoring methods, and they differ in the number of criteria, the accuracy of the description of these criteria and the scoring used. The most frequently used groups of criteria, according to which valorisation of geosites is carried out include: scientific criteria, potential for use along with tourist criteria, and additional criteria (including cultural and aesthetic criteria). All the assessment methods presented so far in the literature are subjective methods, and the valorisation result largely depends only on the knowledge and experience of the expert who carries out the valorisation itself. The author of this article proposes to use the expert triangulation method to reduce the subjectivity of the results obtained as a result of valorisation.
\end{abstract}

Słowa kluczowe: bonitacja punktowa; geostanowisko; geoturystyka; metoda triangulacji; metoda waloryzacji Keywords: assessment method; geomorphosite; geosite; geotourism; scoring methods; triangulation method 
Otrzymano: 13 lipca 2021

Received: 13 July 2021

Zaakceptowano: 6 września 2021

Accepted: 6 September 2021

\section{Sugerowana cytacja / Suggested citation:}

Chrobak, A. (2021). Przegląd metod waloryzacji obiektów przyrody nieożywionej wykorzystywanych w geoturystyce. Prace Komisji Geografii Przemysłu Polskiego Towarzystwa Geograficznego, 35(3), 116-145, doi: https://doi.org/10.24917/20801653.353.8

\section{WSTĘP}

Geoturystyka jako forma turystyki zarówno poznawczej, jak i kwalifikowanej, została po raz pierwszy zdefiniowana w latach 90. XX wieku (Hose, 1995). Jej celem jest podróżowanie do miejsc ciekawych przyrodniczo, szczególnie związanych z formami przyrody nieożywionej widocznymi w krajobrazie (np. Hose, 2000, 2011; Joyce, 2006; Newsome, Dowling, 2010; Ólafsdóttir, 2019; Słomka, Kicińska-Świderska, 2004). Mimo iż historia geoturystyki nie jest długa, to jednak samo podróżowanie do miejsc ciekawych przyrodniczo rozwinęło się już w XV i XVI wieku poprzez odkrywanie nowych lądów, zdobywanie najwyższych szczytów czy poszukiwanie nieznanych form rzeźby (wodospadów, jezior, źródeł rzek itp.). Niewątpliwie ważnym wydarzeniem w rozwoju geoturystyki było utworzenie pierwszego Parku Narodowego Yellowstone w 1872 roku i ochrona jego dziedzictwa geologicznego (Kurek, 2008).

Ideą geoturystyki jest przedstawienie form, a zarazem procesów przyrodniczych w jasny i przystępny sposób (Hose, 2008; Joyce, 2006), wykorzystując przy tym popularnonaukowe publikacje, mapy, przewodniki czy też aplikacje mobilne, wizualizacje 3D, rozszerzone rzeczywistości itd. (Hose, 2000; Newsome, Dowling, 2010; Ólafsdóttir, 2019). Udostępnianie obiektów, tzw. geostanowisk (Reynard, 2004), ma na celu zapewnienie im ochrony i zachowanie ich dziedzictwa przyrodniczego, a także popularyzację nauki i edukację (Alexandrowicz, Alexandrowicz, 2002; Hose, 2000).

Istotnym elementem, który służy wytypowaniu i ocenie geostanowisk, jest ich waloryzacja, opierająca się na metodzie bonitacji punktowej. W ciągu ostatnich dwudziestu lat w literaturze pojawiło się wiele metod waloryzacji, a niniejszy artykuł ma na celu ich analizę i ocenę. Autorka stawia następujące pytania badawcze: 1) Jakie grupy kryteriów służących ocenie geostanowisk występują najczęściej w analizowanych metodach? 2) Jaki jest stopień subiektywności poszczególnych metod? 3) Czy metoda triangulacji pozwoli w pewnym stopniu zmniejszyć subiektywność analizowanych metod?

Aby móc odpowiedzieć na powyższe pytania badawcze, autorka zastosowała następującą metodę porównawczą oraz analizę SWOT (ang. Strengths, Weaknesses, Opportunities, Threats).

\section{CHARAKTERYSTYKA METOD WALORYZACJI GEOSTANOWISK}

Wraz z pojawieniem się szeroko rozumianej geoturystyki w literaturze naukowej na początku przeważały mniej bądź bardziej skomplikowane opisy różnorodnych form związanych z przyrodą nieożywioną (np. Alexandrowicz, 2004; Avanzini i in., 2005; Bartuś, 2015; Costa-Casais, Caetano Alves, 2013; Golonka i in., 2013; Golonka, Krobicki, 2007; Knapik i in., 2011; Krobicki, Golonka, 2008; Krzeszowska, 2013; Sansò i in., 2015; Vdovets, 
Silantiev, Mozzherin, 2010; Wang, 2015). Później zaczęto te obiekty oceniać stosując różnorodne kryteria. Wszystkie dotychczas przedstawione w literaturze metody oceny czy też waloryzacji geostanowisk (ang. geosites) (Reynard, 2004) lub geomorphosites (Reynard, Panizza, 2005) opierają się na bardzo dobrze znanej metodzie bonitacji punktowej, w której poszczególnym kryteriom przypisuje się odpowiednie wartości punktowe, a ich suma daje ostateczną ocenę i pokazuje, czy waloryzowany obiekt jest godny zainteresowania, czy nie. Większość opisanych w literaturze metod waloryzacji i ewaluacji geostanowisk odnosi się do tych, które znajdują się w obszarach górskich lub podgórskich (Alexandrowicz i in., 1992; Brilha, 2016; Cocean, Cocean, 2017; Comănescu, Nedelea, Dobre, 2012; Coratza i in., 2011; Dmytrowski, Kicińska, 2011; Fassoulas i in., 2012; Koźma, 2008; Kubalíková, Kirchner, 2016; Panizza, Mennella, 2007; Pereira, Pereira, 2010; Reynard i in., 2007; Rodrigues, Fonseca, 2010; Rybár, 2010; Zgłobicki i in., 2019; Zouros, 2007). Ostatnio pojawiły się również metody waloryzacji geostanowisk zlokalizowanych w miastach, które opisują naturalne formy rzeźby terenu, które zostały wykorzystane przy lokalizacji miasta, bądź formy antropogeniczne, które powstały przy jego lokacji i późniejszej rozbudowie (tzw. urban geomorphology) (Comănescu, Nedelea, Stănoiu, 2017; Del Monte i in., 2013; Pica i in., 2016, 2017; Reynard, Pica, Coratza, 2017).

\section{KRYTERIA OCENY GEOSTANOWISK}

Kryteria ewaluacji w poszczególnych metodach waloryzacji zależą wyłącznie od wiedzy i doświadczenia autora przygotowującego formularz oceny. Grupy kryteriów, ich liczba, a także skala punktowa jest również kwestią indywidualną badacza, co może później powodować komplikacje przy próbie porównania wyników waloryzacji przy zastosowaniu różnych metod (Reynard, Brilha, 2018).

Analizując poszczególne kryteria waloryzacji geostanowisk można stwierdzić, iż w większości metod pojawiają się trzy główne ich grupy: kryteria naukowe, kryteria dodatkowe (kulturowe, estetyczne) oraz potencjał użytkowania (Reynard, Brilha, 2018) (tabela 1 , rycina 1 ).

Dwa z wymienionych powyżej grup kryteriów (naukowe i dodatkowe) były użyte m.in. w pracach Comănescu, Nedelea, 2010; Feuillet, Sourp, 2011; Niculiţă, Mărgărint, 2018; Reynard i in., 2007; Reynard, Coratza, Hobléa, 2016. Inne dwie grupy (nauka i potencjał użytkowania) znalazły się w pracach Bosson, Reynard, 2012; Del Monte i in., 2013; Pica i in., 2017; Zgłobicki i in., 2019. Wszystkie trzy grupy kryteriów, a także dodatkowo kryteria związane z zarządzaniem, znalazły się w pracach Comănescu, Nedelea, Dobre„2012; Fassoulas i in., 2012; Serrano, González-Trueba, 2005; Zouros, 2007. Kryteria naukowe, turystyczne, potencjał użytkowania oraz dotyczące ochrony przyrody zostały użyte w pracach Coratza i in., 2011; Warowna i in., 2014. Kryteria naukowe dodatkowe, potencjał użytkowania i dotyczące ochrony przyrody, wykorzystali w swych pracach Kubalíková, Kirchner, 2016; Pereira, Pereira, Caetano Alves, 2007; Pereira, Pereira, 2010. Wielu autorów nowych metod waloryzacji, bazując na tych, które wcześniej pojawiły się w literaturze, stworzyło ich kompilacje (Chrobak, 2018; Comănescu, Nedelea, Dobre, 2012; Ilinca, Comănescu, 2011; Kubalíková, 2013; Maghsoudi, Rahmati, 2018; Reynard, Coratza, 2013; Safarabadi, Shahzeidi, 2018), wybierając ich zdaniem najlepsze kryteria z wielu innych. Niektóre metody waloryzacji nie grupują kryteriów, tylko wymieniają według autora najważniejsze, zazwyczaj w takich pracach liczba kryteriów nie przekracza 10 (np. Rybár, 2010) (tabela 1). 
Rycina 1. Grupy kryteriów najczęściej stosowane w 60 analizowanych metodach waloryzacji geostanowisk

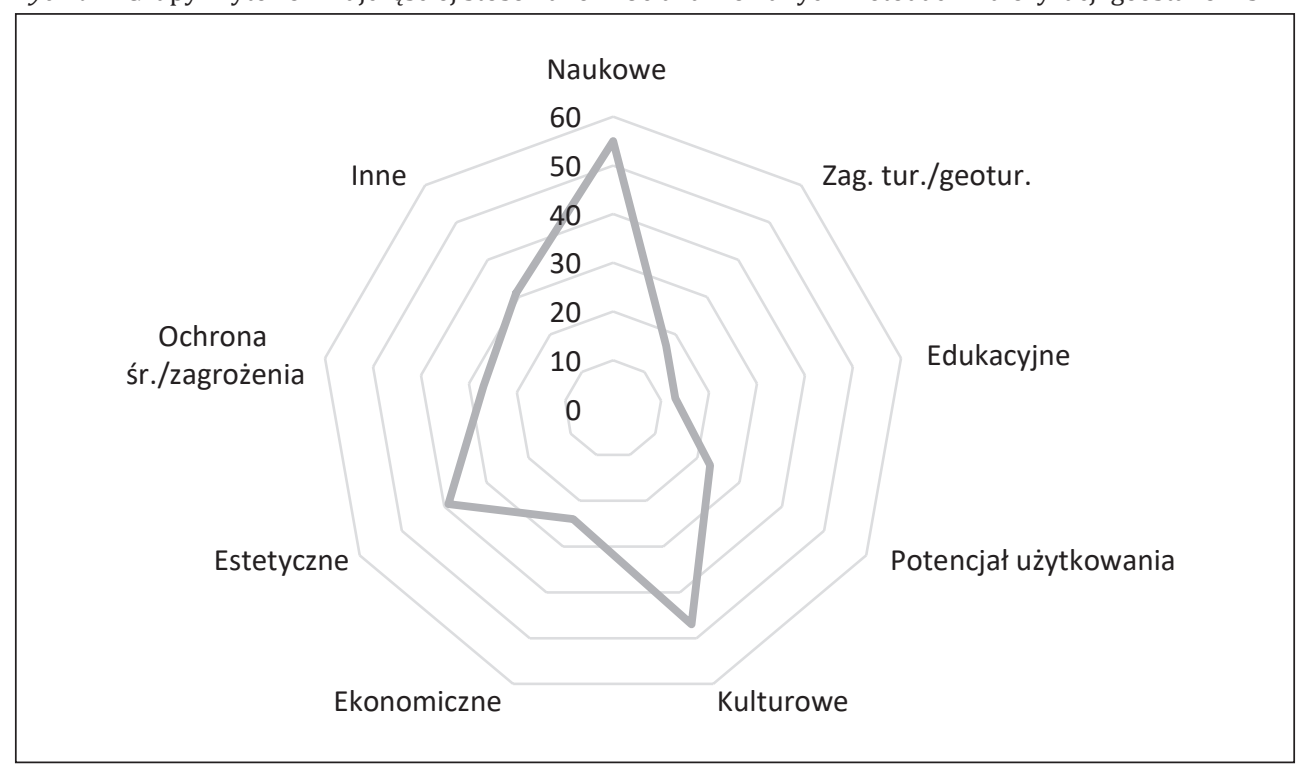

Źródło: opracowanie własne

W grupie kryteriów naukowych najczęściej oceniane są: unikatowość, reprezentatywność w skali analizowanego terenu badań oraz kraju, integralność rozumiana jako stan zachowania obiektu, wiedza naukowa na temat obiektu wyrażona liczbą i rodzajem publikacji, georóżnorodność, paleogeograficzne lub paleogeomorfologiczne znaczenie obiektu, aspekty edukacyjne i ekologiczne, powierzchnia, inne cechy geologiczne, czy warunki obserwacji obiektu z punktów widokowych (Mucivuna i in., 2019). W grupie kryteriów dodatkowych znalazły się: wpływ na środowisko wraz z ochroną obiektu pod kątem wartości ekologicznej, wartości kulturowe, znaczenia: historyczne, religijne, archeologiczne, artystyczne i literaturowe, geohistoryczne, które jest związane bezpośrednio z rolą obiektu w rozwoju nauk o Ziemi, reprezentatywność ikonograficzna oznaczająca przedstawienie obiektu przez artystów malarzy, ikonografików lub rzeźbiarzy, wartości symboliczne, wydarzenia kulturowe i artystyczne, jakie odbywają się w obiekcie lub w bezpośrednim jego sąsiedztwie, współgranie z elementami dziedzictwa kulturowego, estetyczne, kolorowy kontrast, punkty widokowe, struktura przestrzenna, roczna liczba turystów, atrakcyjność, potencjał ekonomiczny, naturalne ryzyka dla wartości ekonomicznych. Grupa kryteriów potencjału użytkowego (turystycznych) składała się głównie z kryteriów: dostępności, widoczności, wykorzystania edukacyjnego, infrastruktury, wyposażenia i usług dodatkowych, średniej odległości od punktu widokowego, występowania produktów edukacyjnych, wykorzystania wartości kulturowych, obecnego wykorzystania innych przyrodniczych i/lub kulturowych wartości, obecnego wykorzystania wartości geomorfologicznych, reprezentatywności, wartości dodatkowych, statusu ochrony czy stosowania ograniczeń. Wreszcie w grupie kryteriów dotyczących zarządzania i ochrony środowiska znalazły się: wrażliwość, kruchość, stopień ochrony, występowanie zagrożeń lub potencjalne zagrożenia i wpływy, integralność, status stanowiska (Mucivuna i in., 2019) (tabela 1). 


\begin{tabular}{|c|c|c|c|c|c|c|c|}
\hline 壱 & 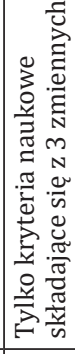 & & 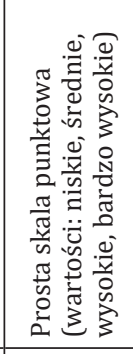 & & 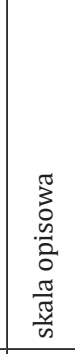 & 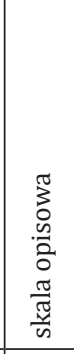 & 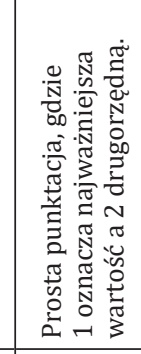 \\
\hline 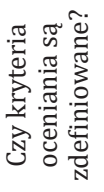 & $\frac{\omega}{z}$ & 递 & $\frac{w}{z}$ & $\underline{\underline{z}}$ & $\frac{\omega}{z}$ & $\frac{w}{z}$ & 递 \\
\hline 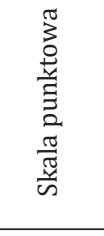 & 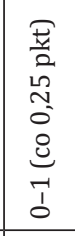 & 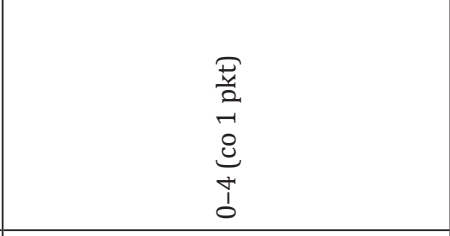 & $\begin{array}{l}\vec{F} \\
\frac{\vec{y}}{2} \\
\sim \\
0 \\
0 \\
0 \\
0 \\
\overrightarrow{0} \\
0 \\
0\end{array}$ & 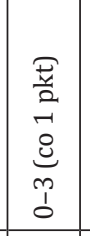 & 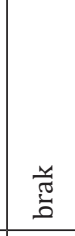 & 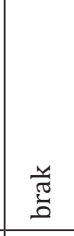 & 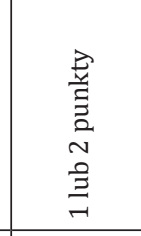 \\
\hline 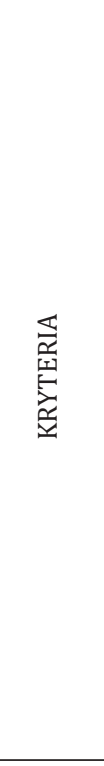 & 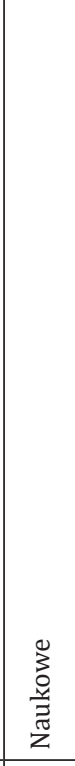 & 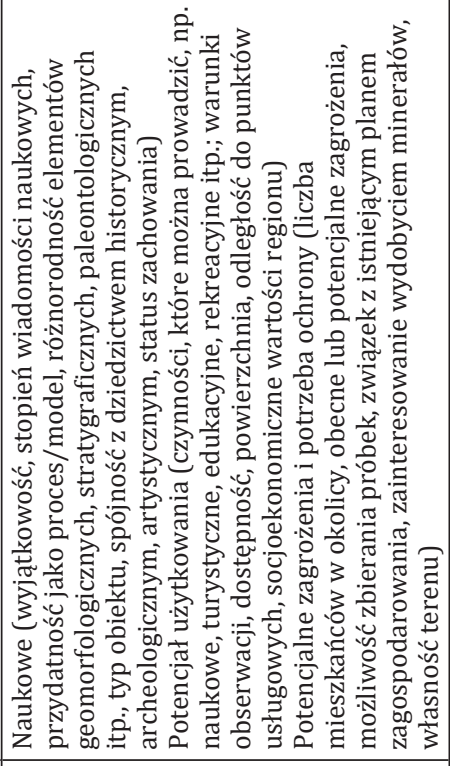 & 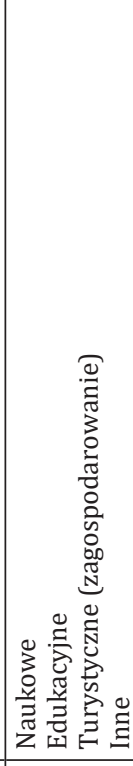 & 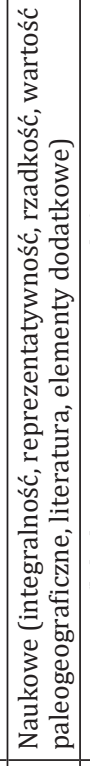 & 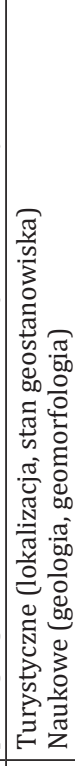 & 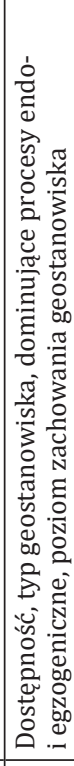 & 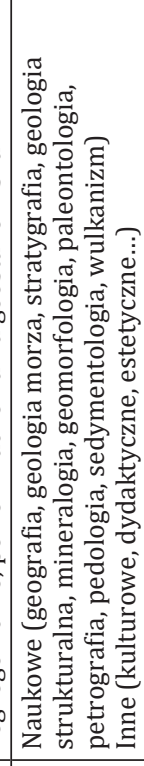 \\
\hline 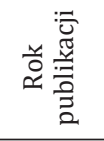 & 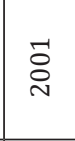 & 号 & $\stackrel{\text { L }}{\stackrel{\text { N }}{2}}$ & 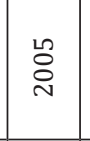 & $\begin{array}{l}\stackrel{L}{\circ} \\
\stackrel{\sim}{\sim}\end{array}$ & $\stackrel{\text { ڤે }}{\stackrel{\sim}{N}}$ & 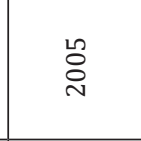 \\
\hline 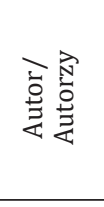 & $\begin{array}{l}\mathbb{N} \\
\stackrel{\mathbb{N}}{\widetilde{\Xi}} \\
\widetilde{\Xi} \\
\end{array}$ & 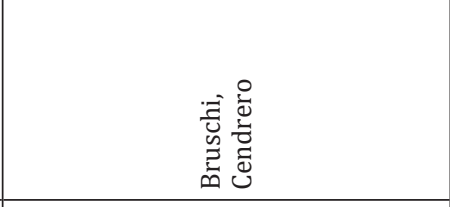 & 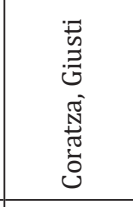 & $\begin{array}{l}\pi \\
\tilde{0} \\
\tilde{J} \\
\tilde{\Xi} \\
\tilde{J} \\
0 \\
0\end{array}$ & 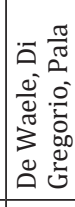 & 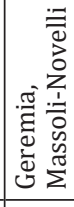 & 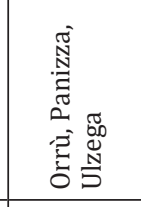 \\
\hline فئ & $\rightarrow$ & N & $m$ & $\sigma$ & ᄂ & 0 & $\wedge$ \\
\hline
\end{tabular}




\begin{tabular}{|c|c|c|}
\hline 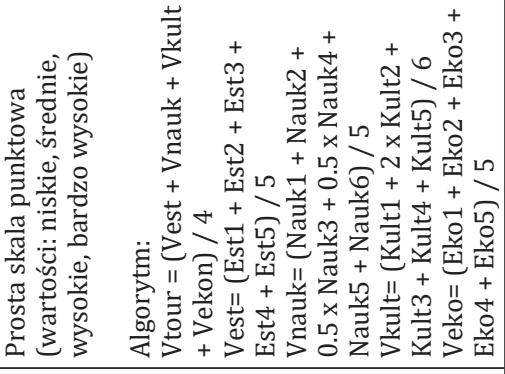 & 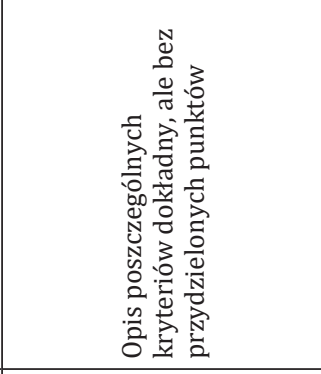 & 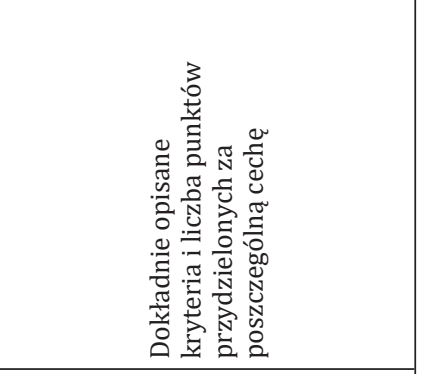 \\
\hline 띨 & 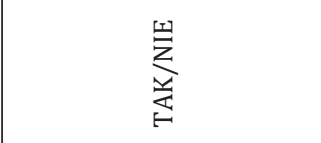 & 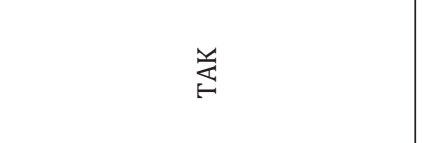 \\
\hline 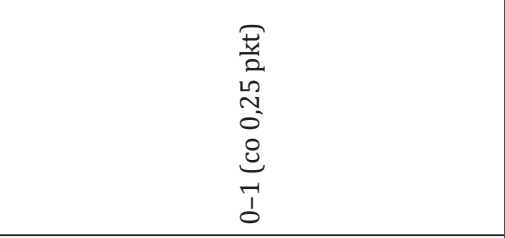 & 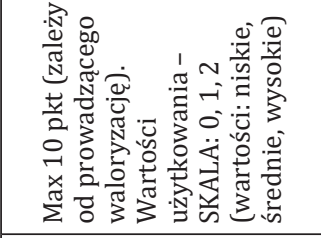 & 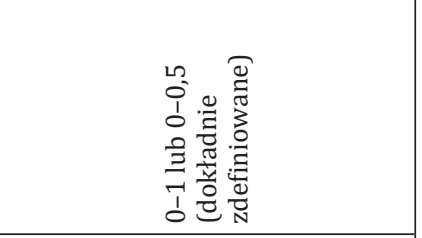 \\
\hline 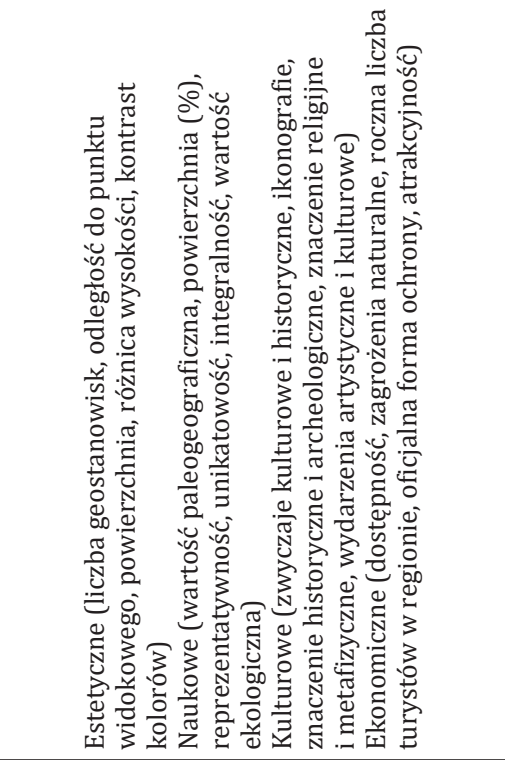 & 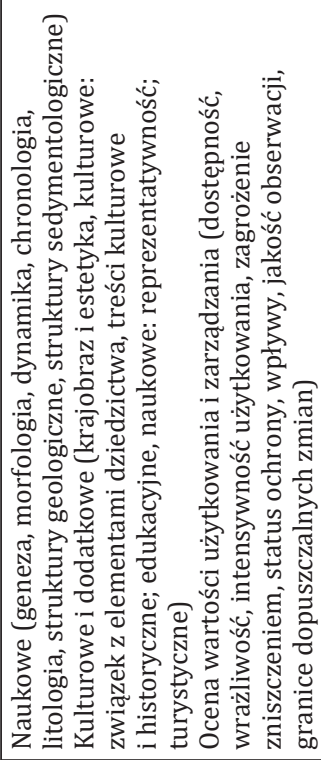 & 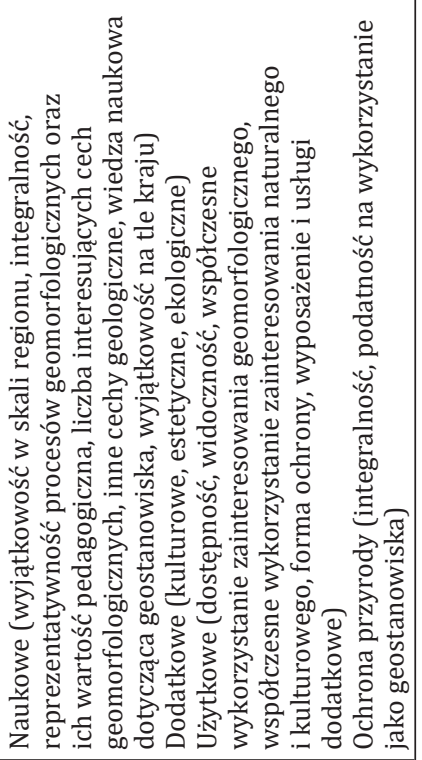 \\
\hline $\begin{array}{l}\text { 옹 } \\
\stackrel{\overbrace{}}{N}\end{array}$ & 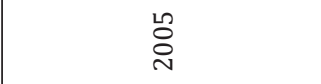 & 今̊ \\
\hline 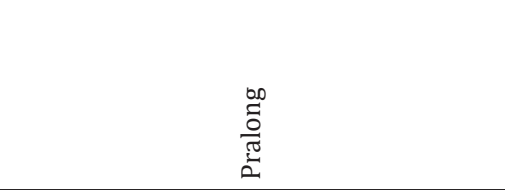 & 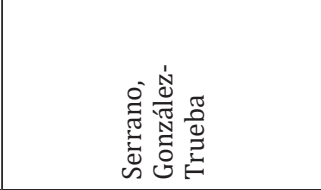 & 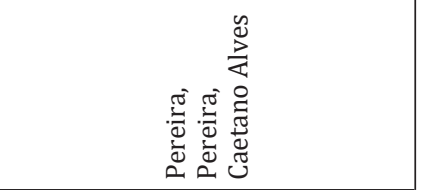 \\
\hline$\infty$ & $\sigma$ & $\stackrel{\circ}{\circ}$ \\
\hline
\end{tabular}




\begin{tabular}{|c|c|c|c|}
\hline 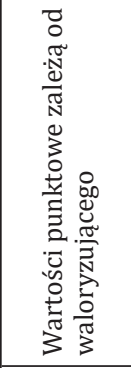 & 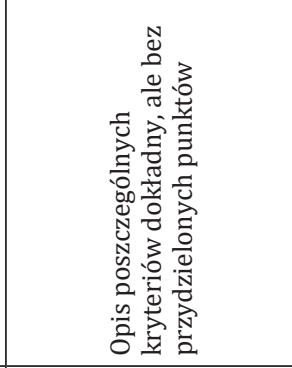 & 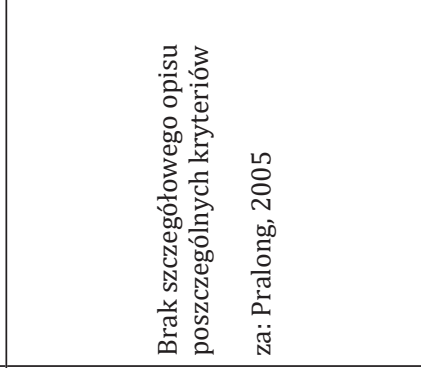 & 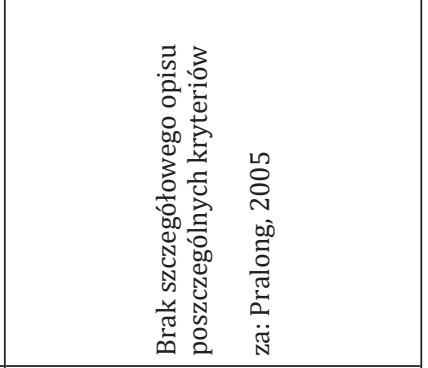 \\
\hline 坛 & 舀 & $\frac{1}{z}$ & 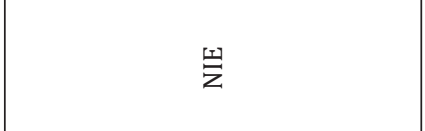 \\
\hline$\vec{\jmath}$ & 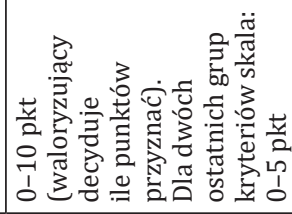 & 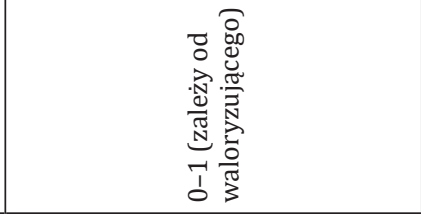 & 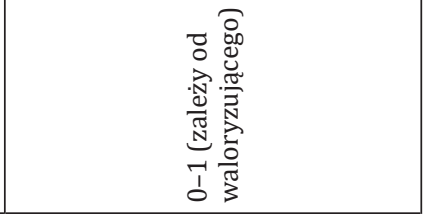 \\
\hline 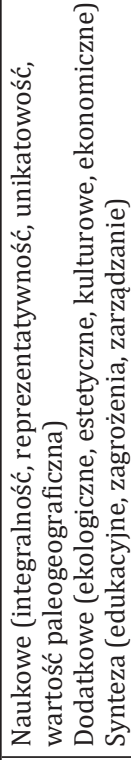 & 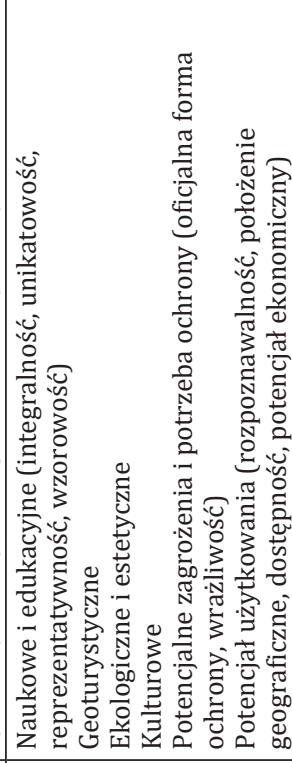 & 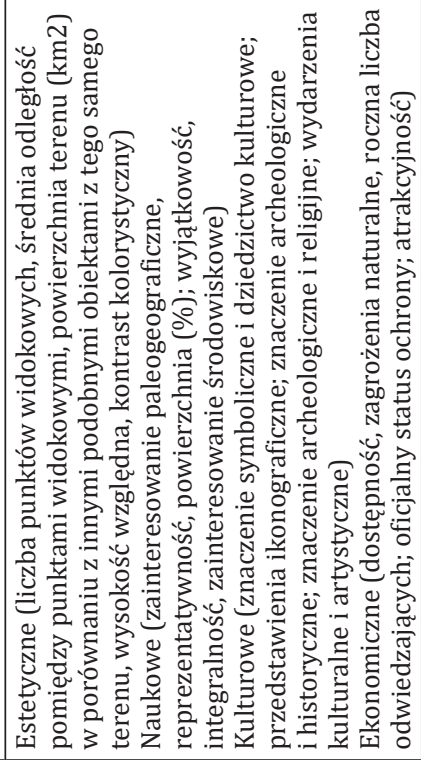 & 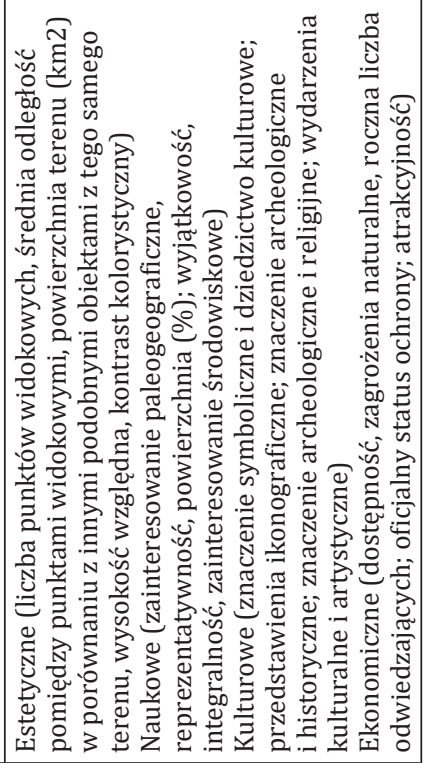 \\
\hline 今̊ & $\begin{array}{l}\text { Oे } \\
\text { ¿ }\end{array}$ & 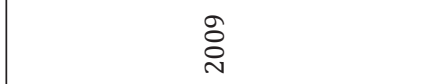 & 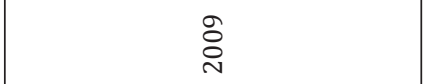 \\
\hline 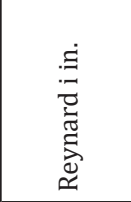 & 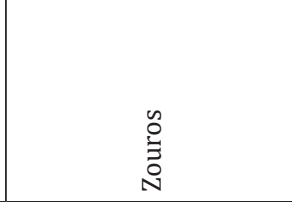 & 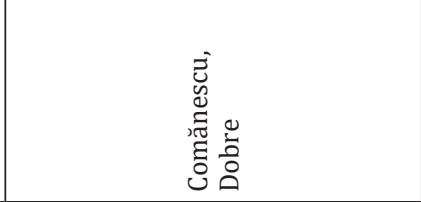 & 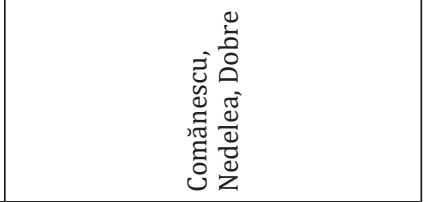 \\
\hline$\exists$ & $\approx$ & $\stackrel{m}{\rightarrow}$ & $\mathbb{Z}$ \\
\hline
\end{tabular}




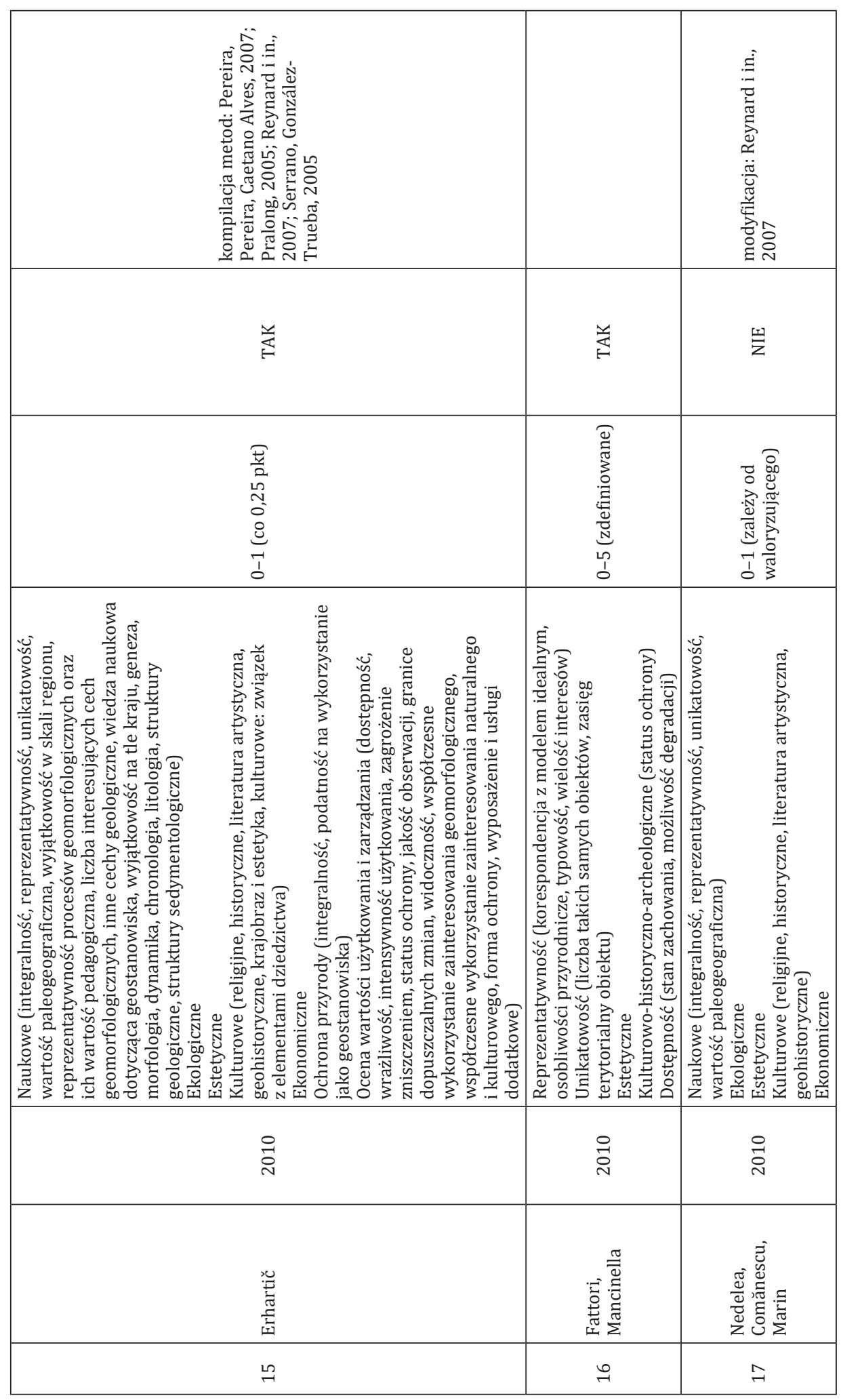




\begin{tabular}{|c|c|c|}
\hline 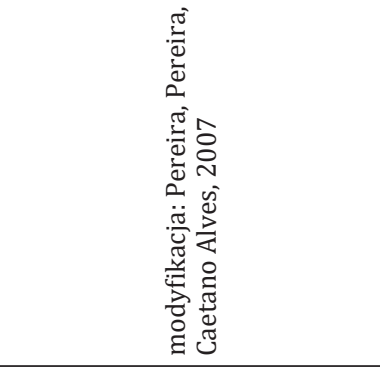 & 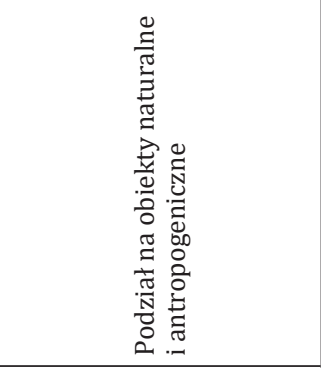 & 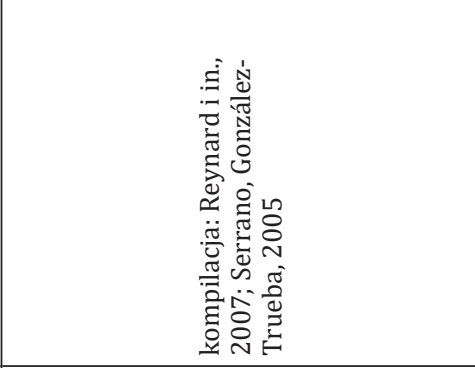 \\
\hline 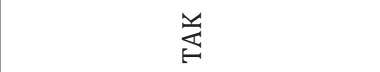 & 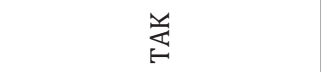 & 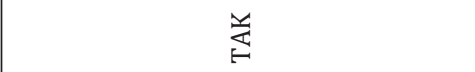 \\
\hline 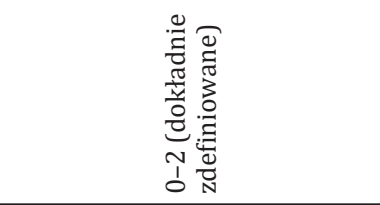 & 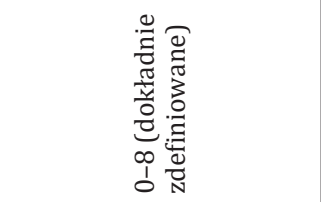 & $\begin{array}{l}0 \\
\stackrel{1}{1} \\
0\end{array}$ \\
\hline 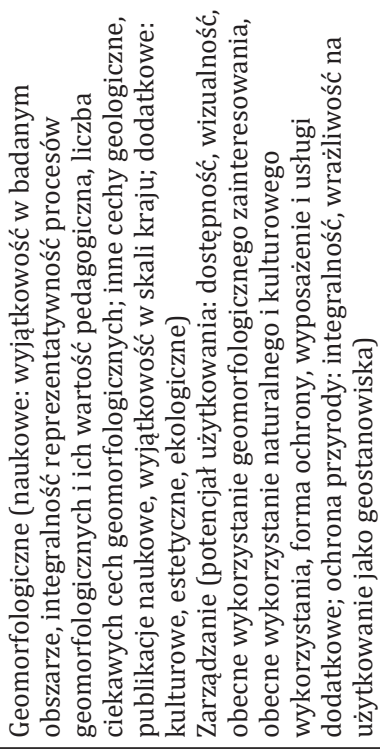 & 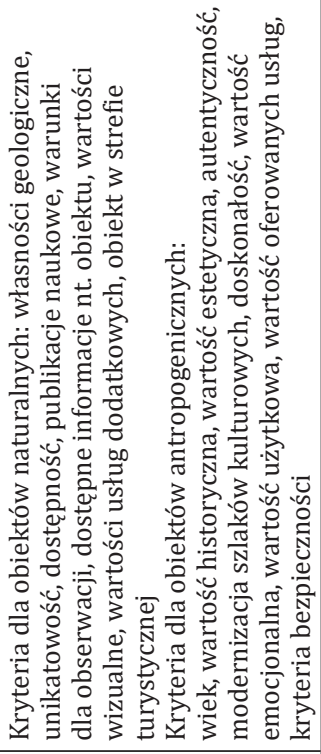 & 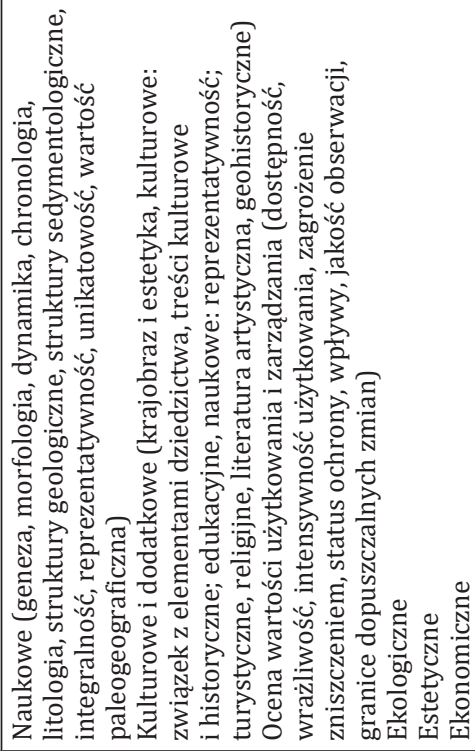 \\
\hline 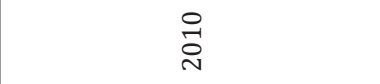 & 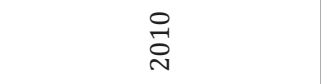 & $\vec{\sim}$ \\
\hline 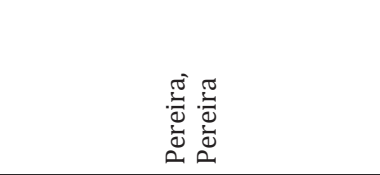 & 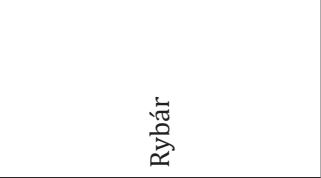 & 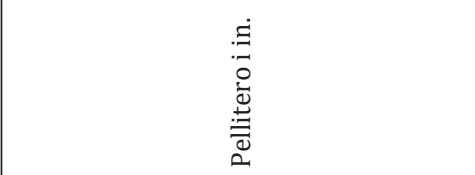 \\
\hline$\stackrel{\infty}{\sim}$ & $\stackrel{\sigma}{\sim}$ & ㄱ \\
\hline
\end{tabular}




\begin{tabular}{|c|c|c|c|}
\hline 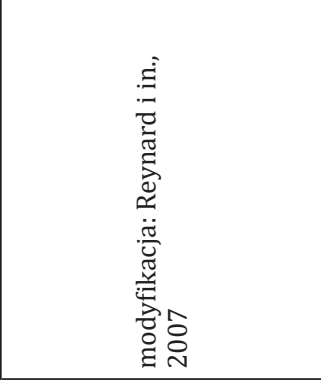 & 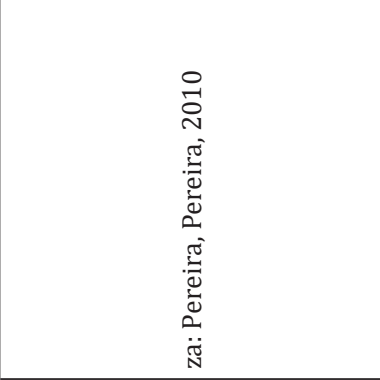 & 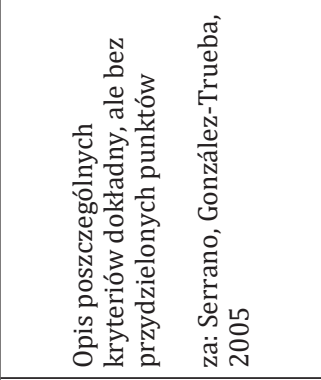 & 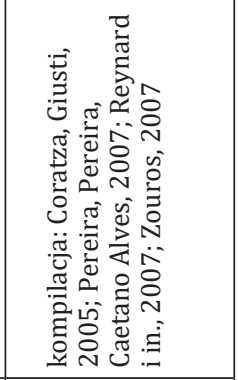 \\
\hline 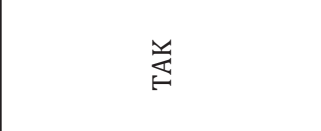 & 死 & 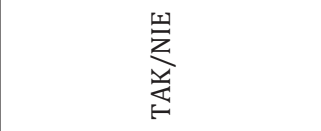 & 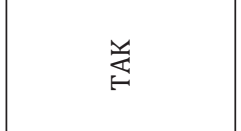 \\
\hline 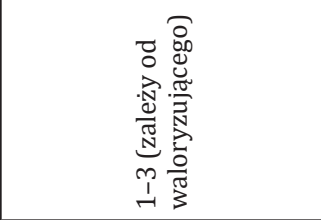 & 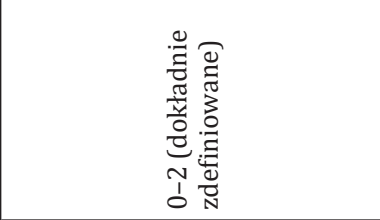 & $\begin{array}{l}0 \\
\stackrel{1}{1}\end{array}$ & 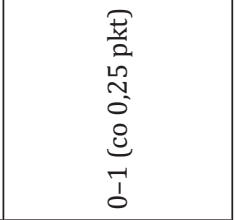 \\
\hline 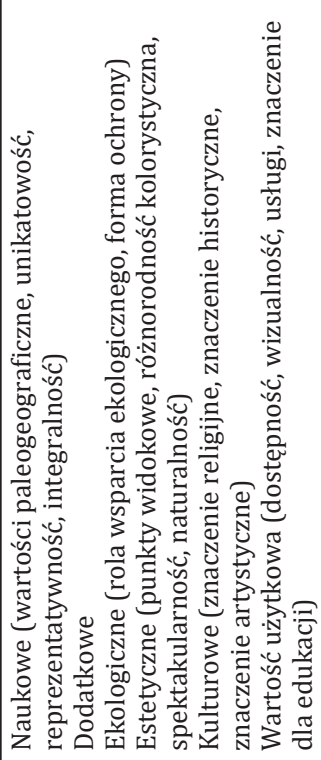 & 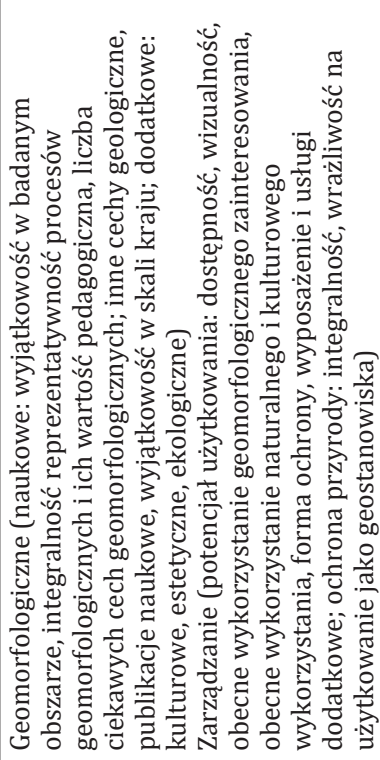 & 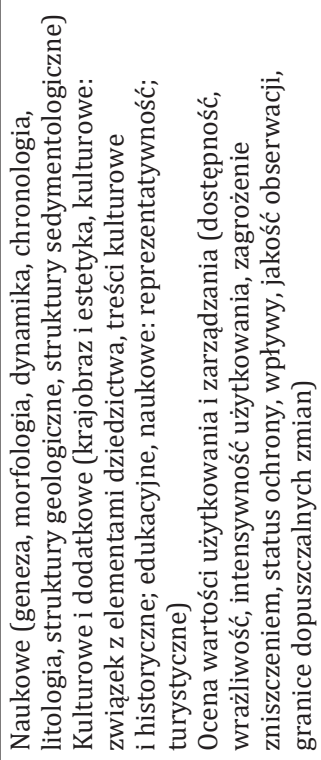 & 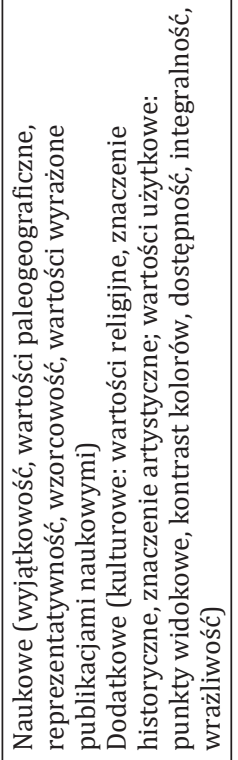 \\
\hline$\underset{\sim}{\vec{D}}$ & ָ) & $\overrightarrow{\stackrel{a}{\sim}}$ & $\stackrel{\sim}{\circ}$ \\
\hline 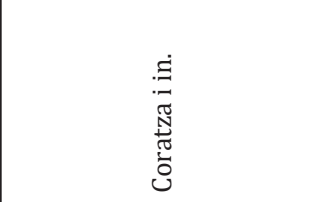 & jo & 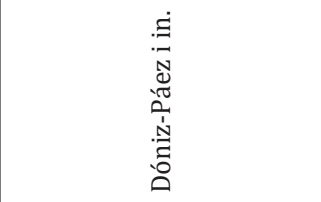 & 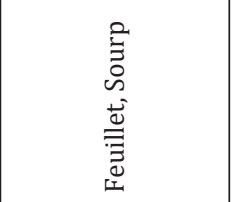 \\
\hline$\vec{N}$ & $\mathbb{N}$ & $\stackrel{2}{\sim}$ & 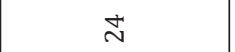 \\
\hline
\end{tabular}




\begin{tabular}{|c|c|c|}
\hline 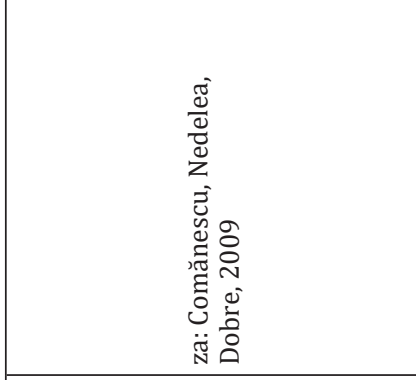 & 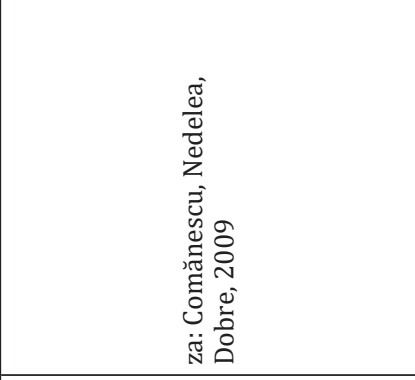 & 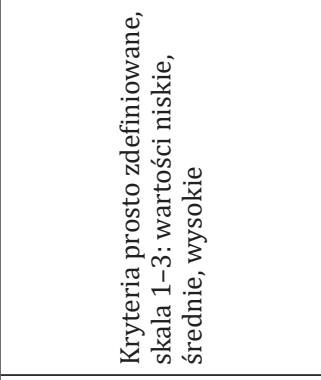 \\
\hline 嶤 & $\frac{\omega}{z}$ & 冚 \\
\hline 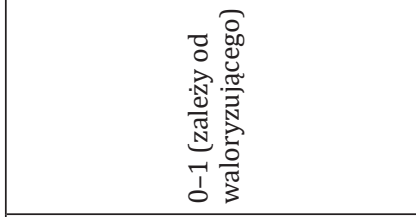 & 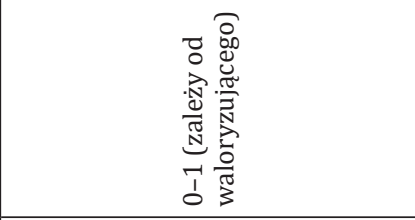 & $\begin{array}{l}\frac{\pi}{2} \\
\frac{\pi}{2} \\
-1 \\
0 \\
0 \\
1 \\
1\end{array}$ \\
\hline 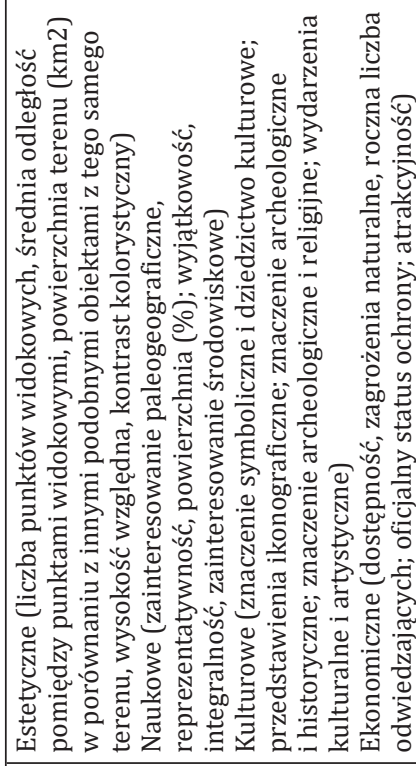 & 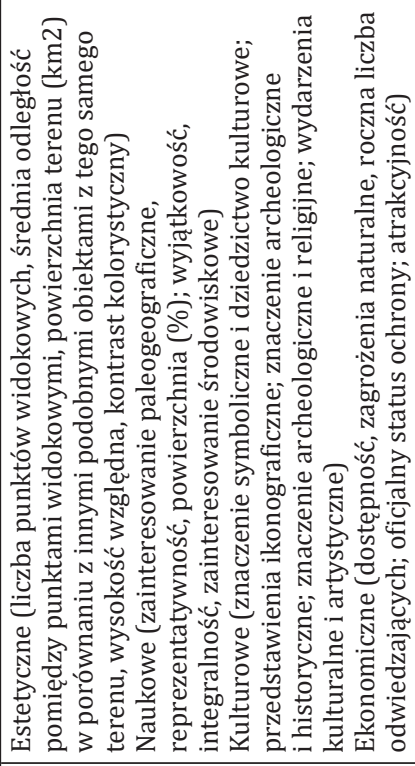 & 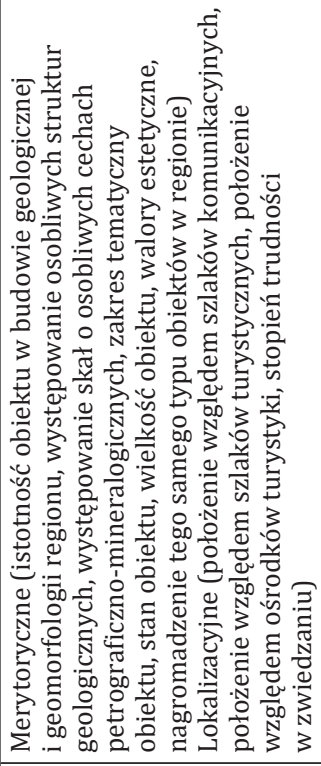 \\
\hline$\underset{\sim}{\stackrel{\sim}{*}}$ & $\underset{\sim}{\vec{\sim}}$ & $\underset{\sim}{\stackrel{\sim}{0}}$ \\
\hline 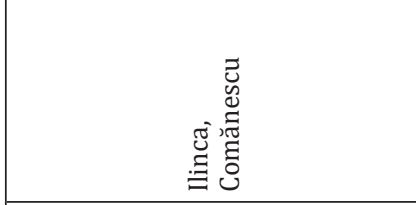 & 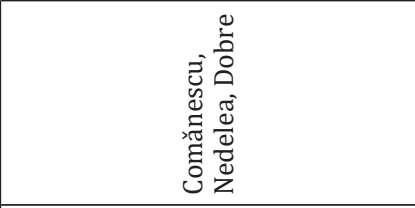 & 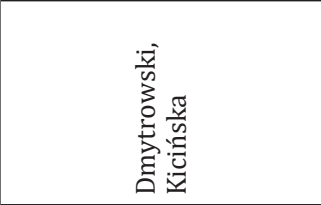 \\
\hline$\stackrel{\llcorner}{\sim}$ & $\stackrel{\sim}{\sim}$ & $\hat{\sim}$ \\
\hline
\end{tabular}




\begin{tabular}{|c|c|c|c|}
\hline & 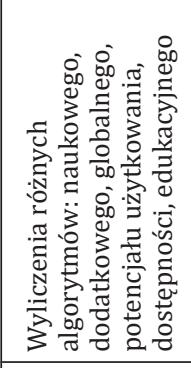 & 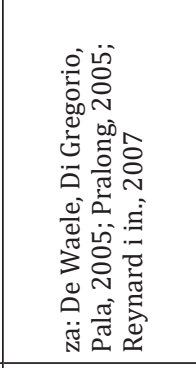 & 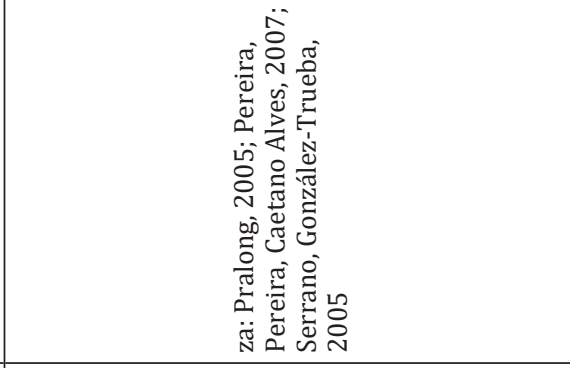 \\
\hline & 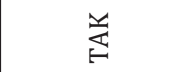 & 息 & 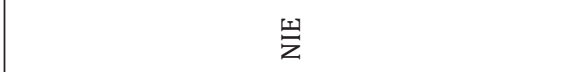 \\
\hline & 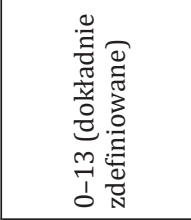 & 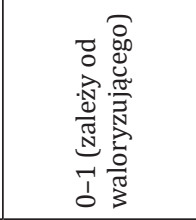 & 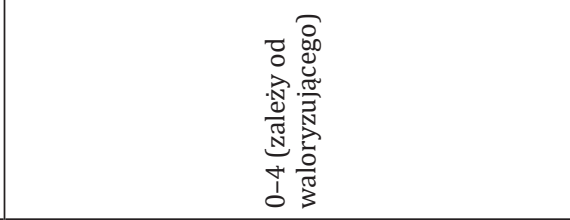 \\
\hline \multirow[t]{3}{*}{ 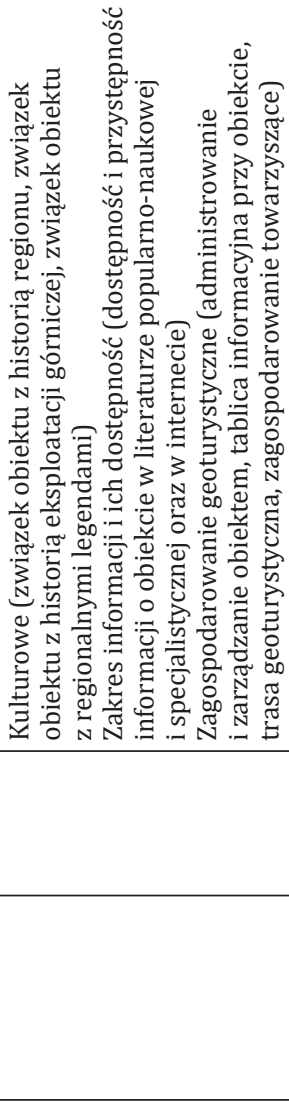 } & 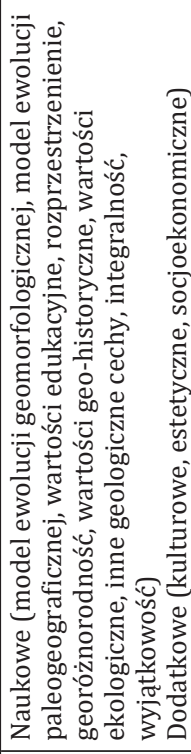 & 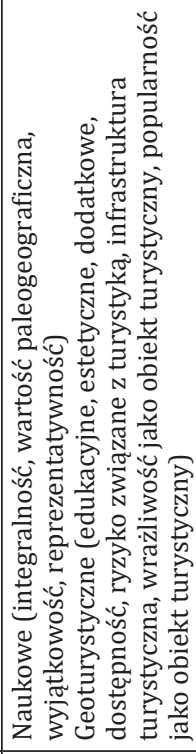 & 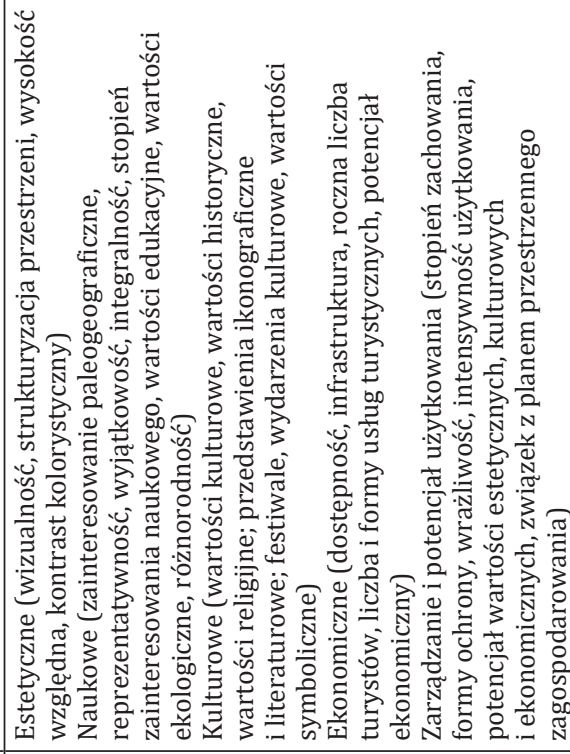 \\
\hline & $\underset{\sim}{\stackrel{\sim}{\sim}}$ & $\underset{\sim}{\stackrel{\sim}{*}}$ & 곡 \\
\hline & 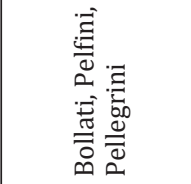 & 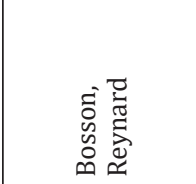 & 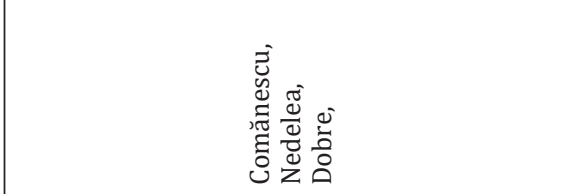 \\
\hline$\widehat{N}$ & $\stackrel{\infty}{\sim}$ & $\stackrel{\curvearrowright}{\sim}$ & pి \\
\hline
\end{tabular}




\begin{tabular}{|c|c|c|c|c|}
\hline 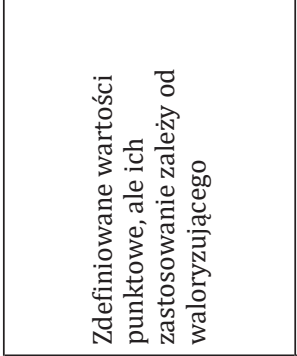 & 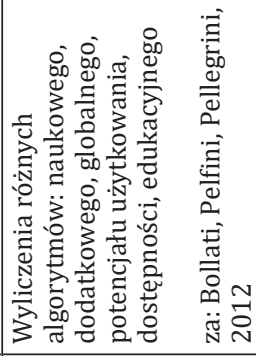 & 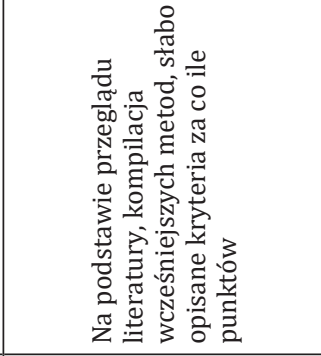 & & 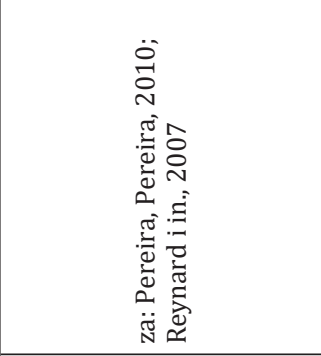 \\
\hline 芯 & $\underset{E}{\stackrel{U}{E}}$ & $\frac{1}{z}$ & $\underset{E}{\stackrel{U}{E}}$ & 芯 \\
\hline 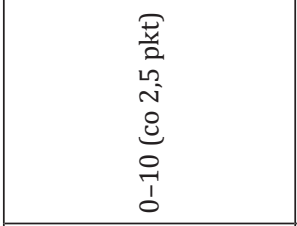 & 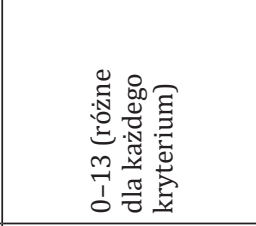 & ! & 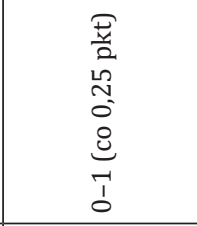 & 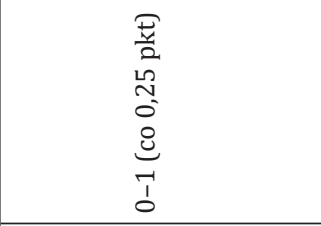 \\
\hline 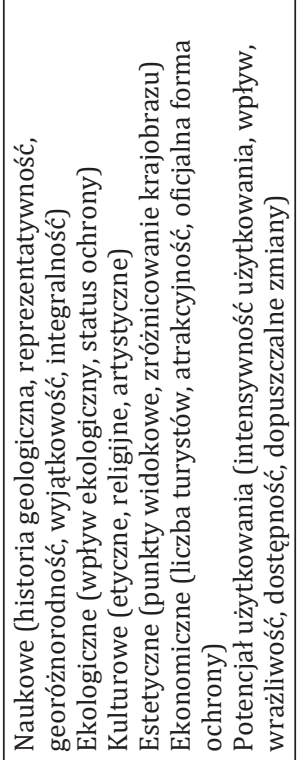 & 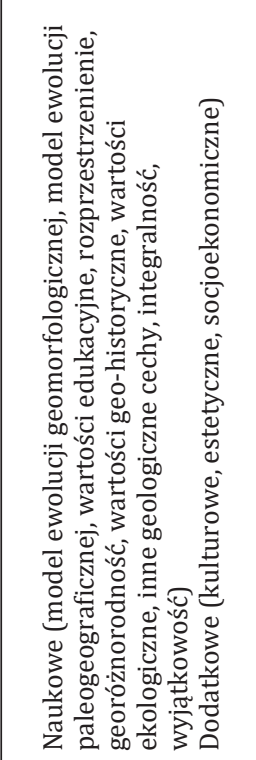 & 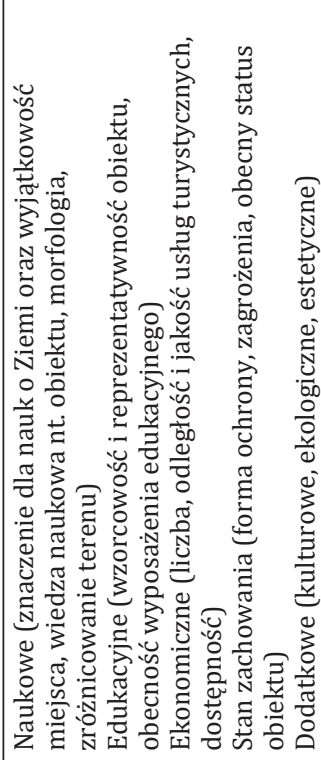 & 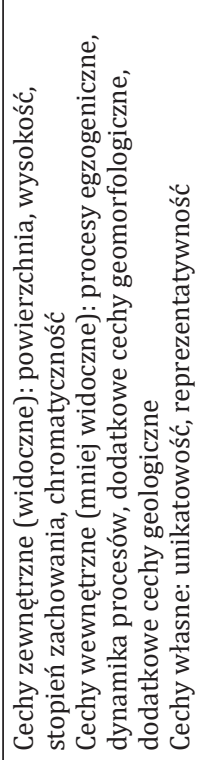 & 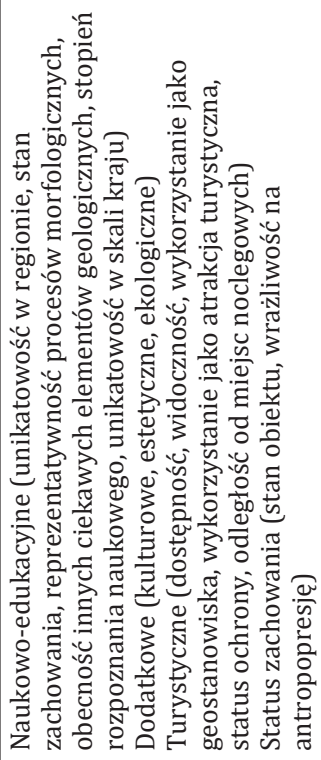 \\
\hline$\underset{\sim}{\stackrel{\sim}{*}}$ & $\stackrel{m}{\stackrel{m}{*}}$ & $\stackrel{m}{\stackrel{2}{\sim}}$ & $\stackrel{m}{\stackrel{n}{\sim}}$ & $\underset{\sim}{\stackrel{\sim}{*}}$ \\
\hline 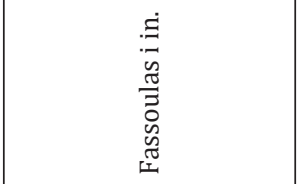 & 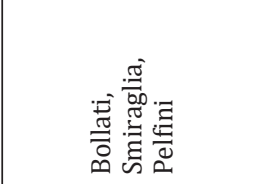 & 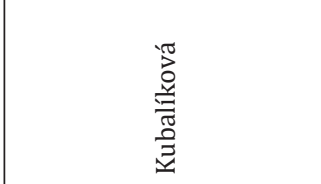 & $\begin{array}{l}\text { 员 } \\
\text { Z }\end{array}$ & 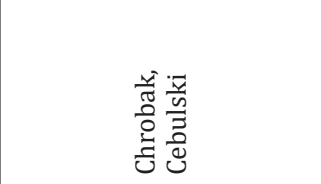 \\
\hline$\vec{m}$ & $\tilde{m}$ & $\ddot{m}$ & ळे & $\stackrel{\text { Ln }}{m}$ \\
\hline
\end{tabular}




\begin{tabular}{|c|c|c|c|}
\hline 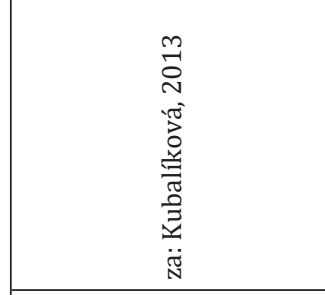 & & 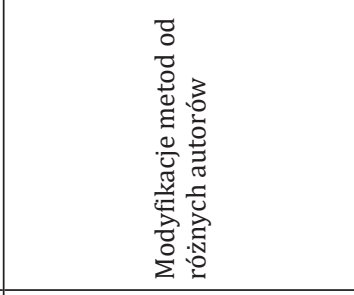 & \\
\hline$\underset{F}{~}$ & 产 & 迹 & 产 \\
\hline 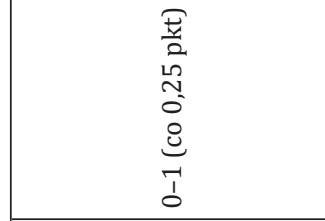 & 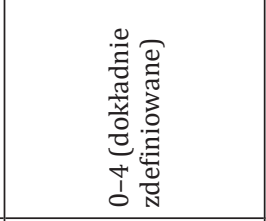 & 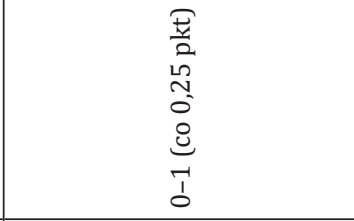 & 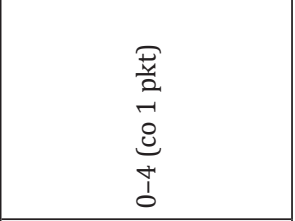 \\
\hline 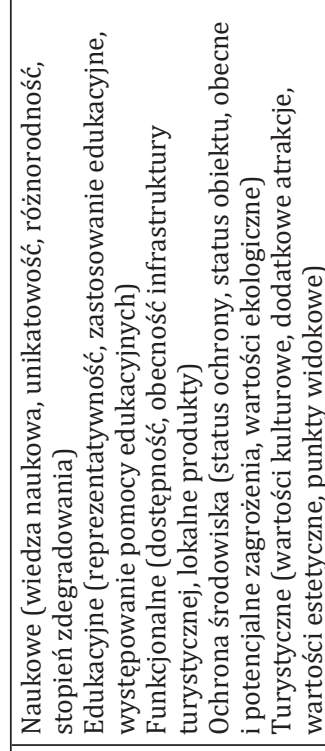 & 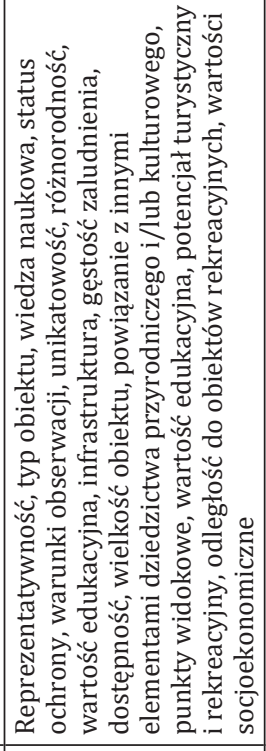 & 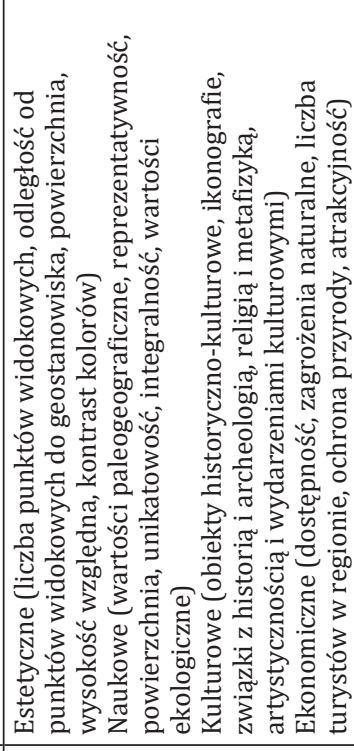 & 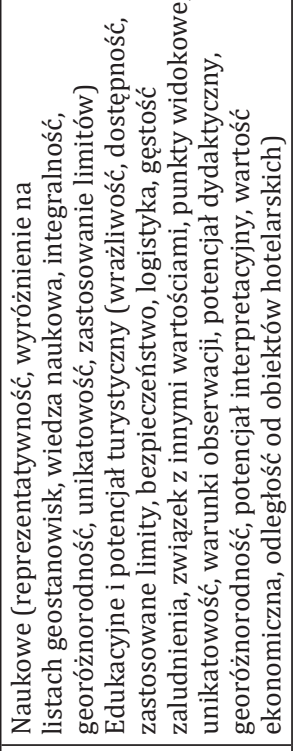 \\
\hline$\underset{\sim}{\stackrel{H}{*}}$ & $\stackrel{\sim}{\stackrel{2}{\sim}}$ & $\begin{array}{l}\stackrel{0}{\stackrel{N}{*}} \\
\text {. }\end{array}$ & $\begin{array}{l}0 \\
\stackrel{1}{N}\end{array}$ \\
\hline 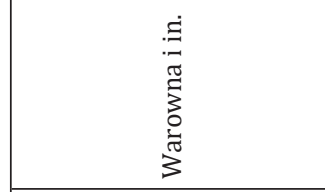 & 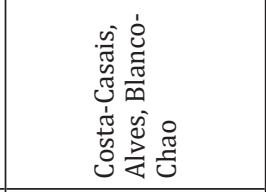 & $\stackrel{\tilde{\sigma}}{z}$ & 寻 \\
\hline$\stackrel{m}{m}$ & $\hat{m}$ & $\stackrel{m}{m}$ & $\dot{m}$ \\
\hline
\end{tabular}




\begin{tabular}{|c|c|c|}
\hline 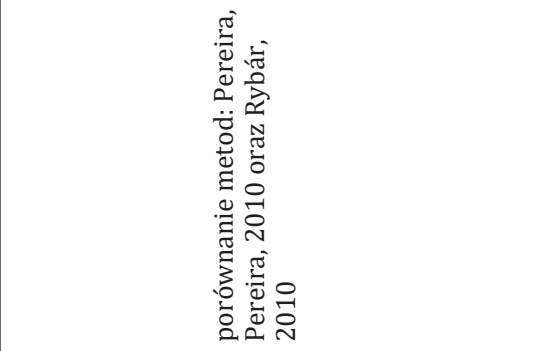 & 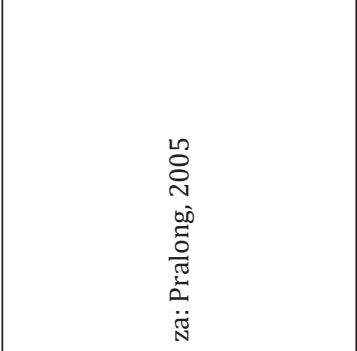 & 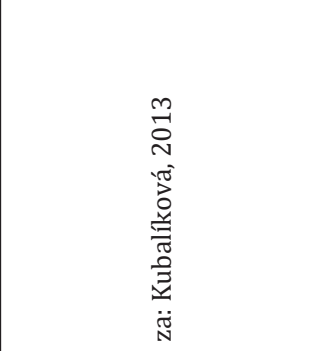 \\
\hline 芯 & 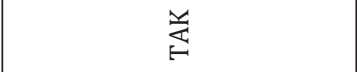 & $\underset{巨}{\stackrel{y}{\leftrightarrows}}$ \\
\hline $\begin{array}{l}\frac{\vec{y}}{2} \\
0 \\
1 \\
0 \\
-\vec{z} \\
\frac{\vec{z}}{2} \\
N \\
1 \\
0\end{array}$ & 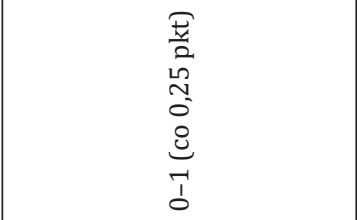 & $\vec{\jmath}$ \\
\hline 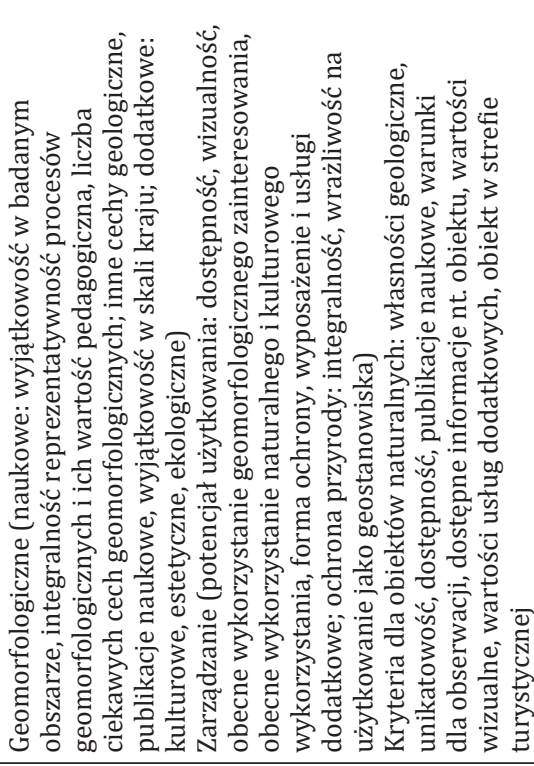 & 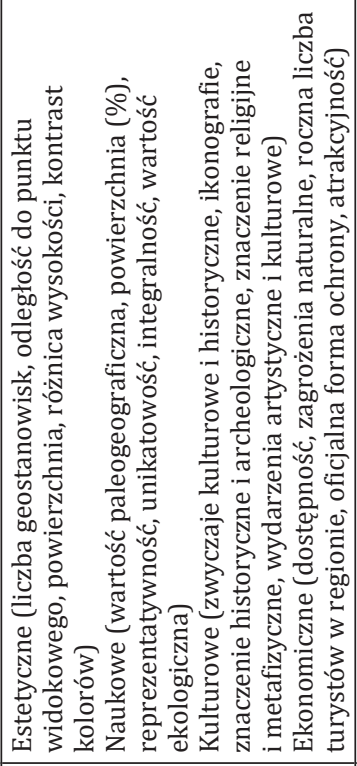 & 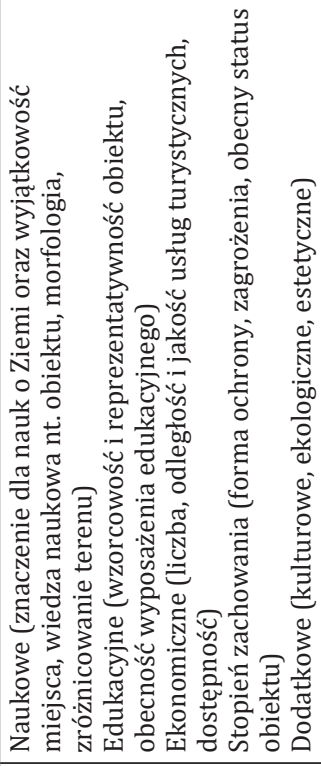 \\
\hline $\begin{array}{l}0 \\
\stackrel{\sim}{*}\end{array}$ & $\begin{array}{l}0 \\
\stackrel{\sim}{\sim}\end{array}$ & $\begin{array}{l}0 \\
\stackrel{\sim}{N}\end{array}$ \\
\hline 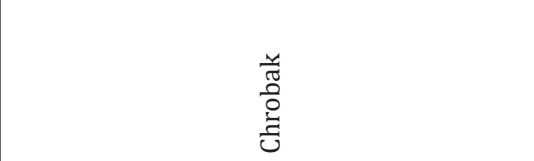 & $\Xi$ & 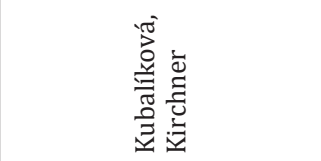 \\
\hline 우 & $F$ & F \\
\hline
\end{tabular}




\begin{tabular}{|c|c|c|c|c|}
\hline 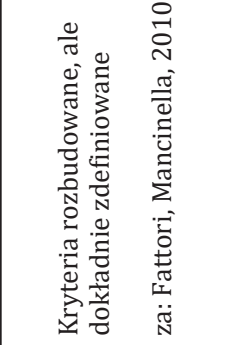 & & 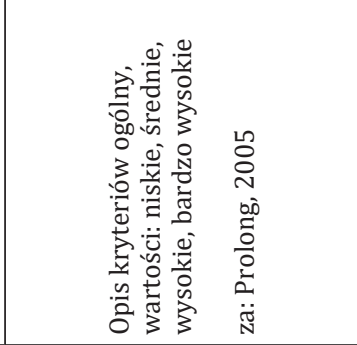 & & 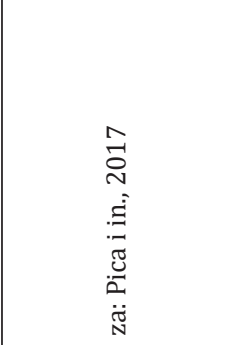 \\
\hline 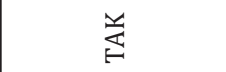 & 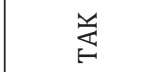 & $\frac{\omega}{z}$ & 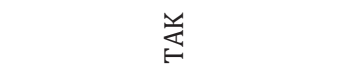 & $\underset{બ}{\stackrel{\rightleftarrows}{\leftrightarrows}}$ \\
\hline $\begin{array}{l}1 \\
1 \\
0\end{array}$ & $\grave{b}$ & 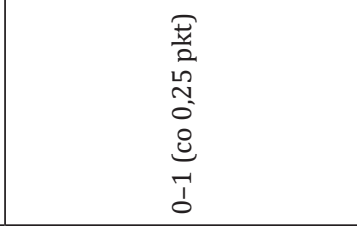 & $\stackrel{m}{1}$ & 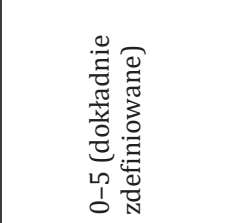 \\
\hline 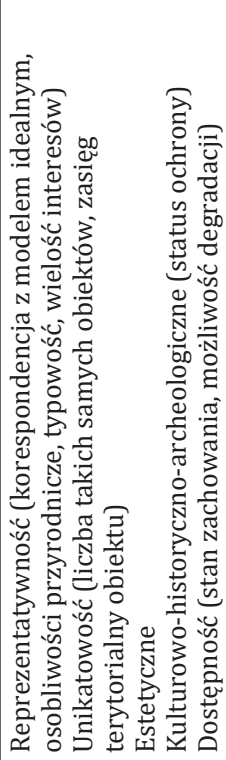 & 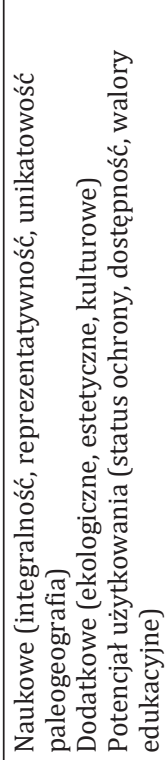 & 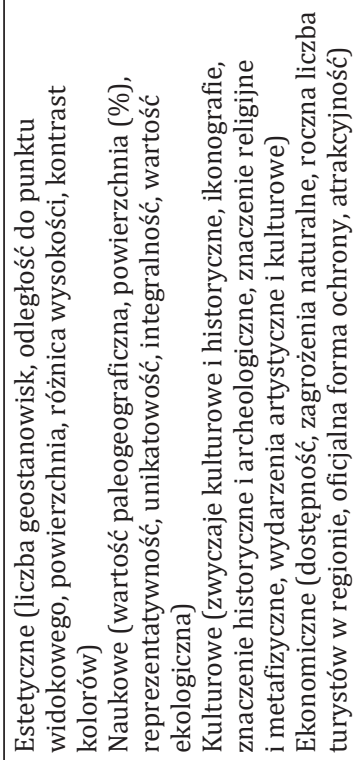 & 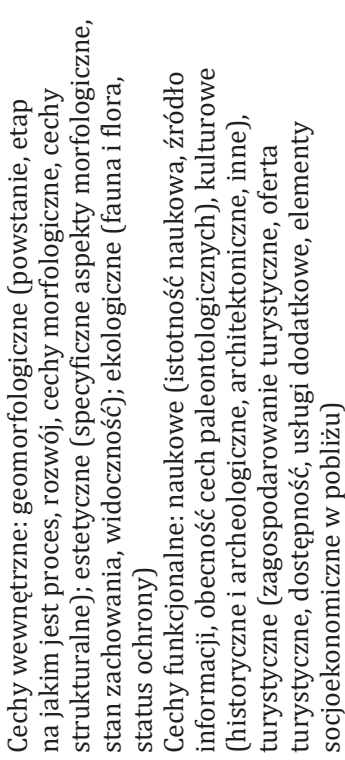 & 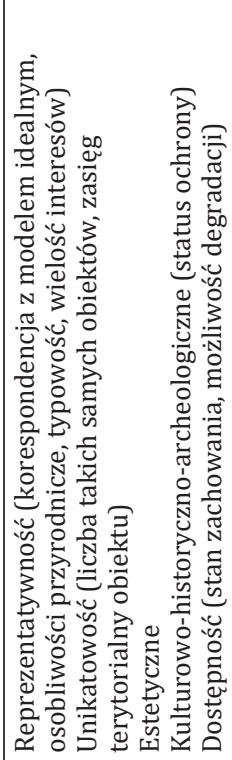 \\
\hline $\begin{array}{l}0 \\
\stackrel{\sim}{\sim}\end{array}$ & $\begin{array}{l}0 \\
\stackrel{\sim}{\sim}\end{array}$ & $\overrightarrow{\text { Dे }}$ & $\vec{\sim}$ & $\vec{\sim}$ \\
\hline 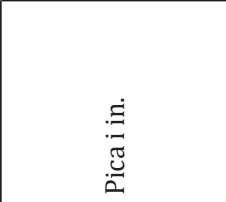 & 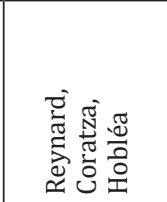 & 惫 & 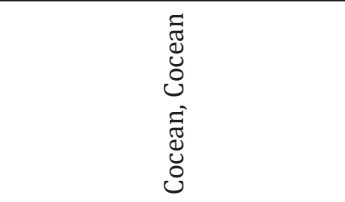 & تِّ. \\
\hline$\stackrel{m}{+}$ & F & 饮 & f & \& \\
\hline
\end{tabular}




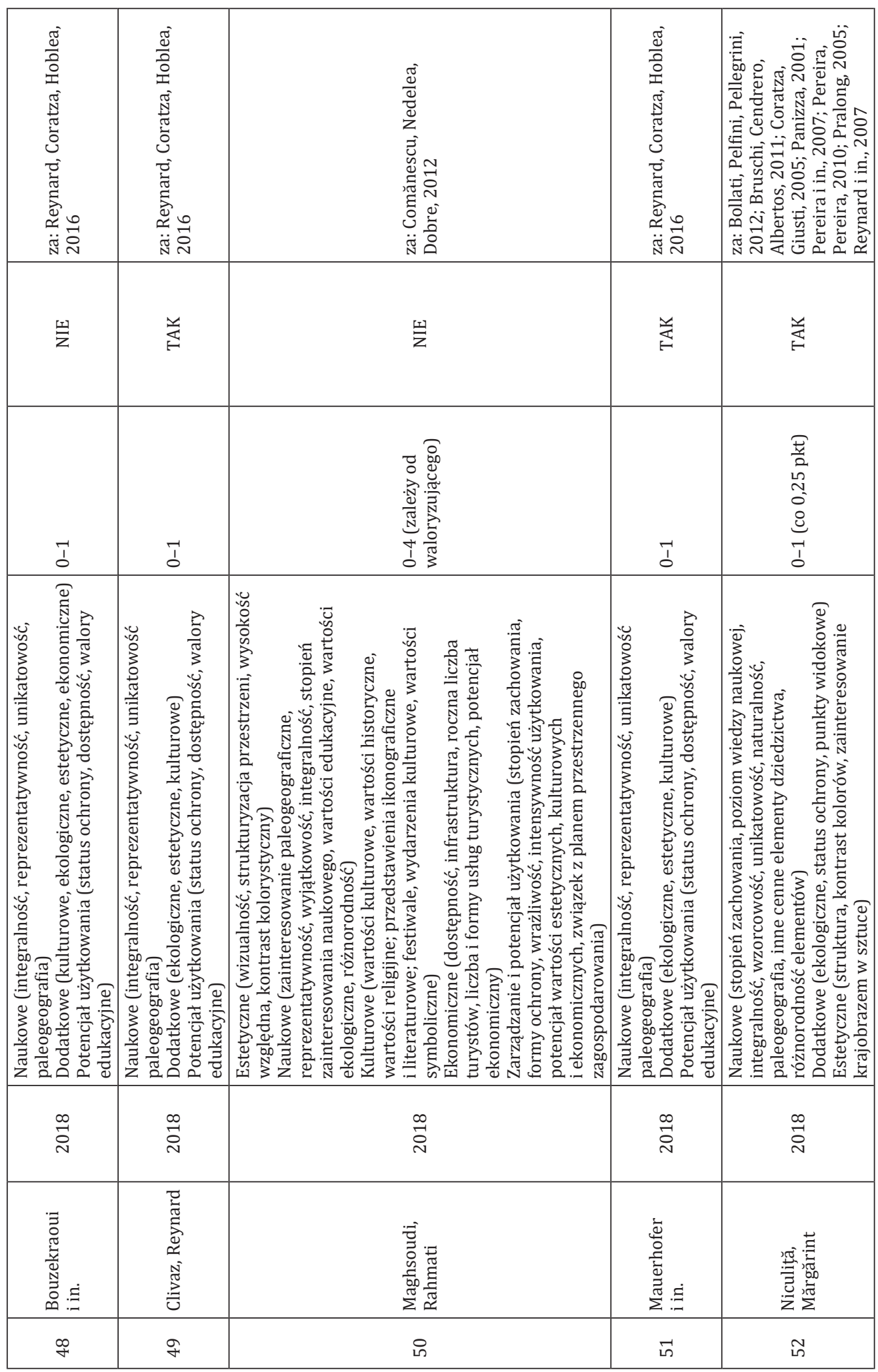




\begin{tabular}{|c|c|c|c|c|}
\hline & 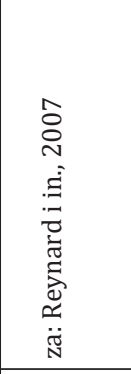 & 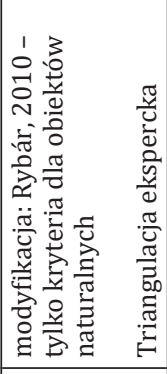 & 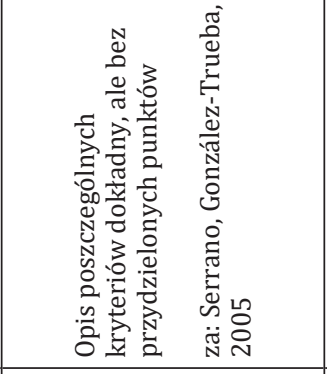 & 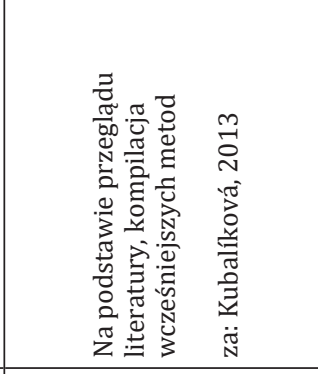 \\
\hline & $\underset{E}{\stackrel{\swarrow}{\rightleftarrows}}$ & 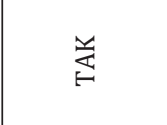 & 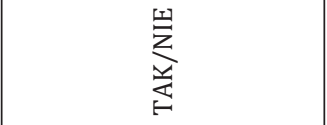 & 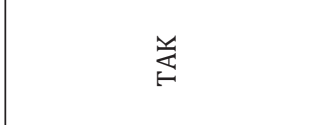 \\
\hline & 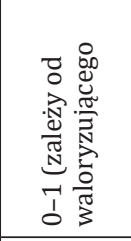 & $\begin{array}{l}\infty \\
1 \\
0\end{array}$ & 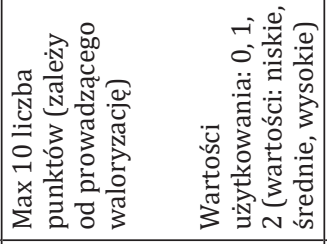 & $\vec{b}$ \\
\hline \multirow[t]{3}{*}{ 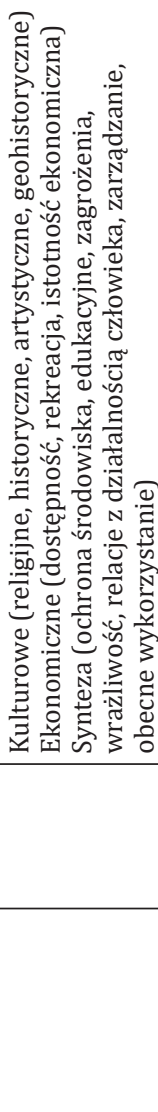 } & 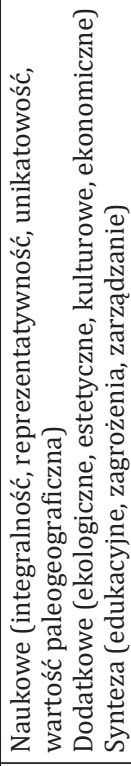 & 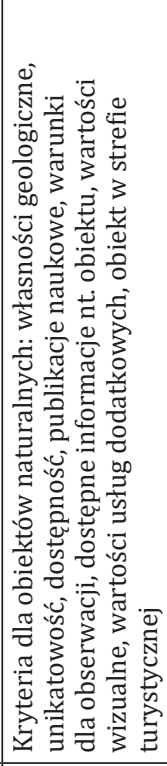 & 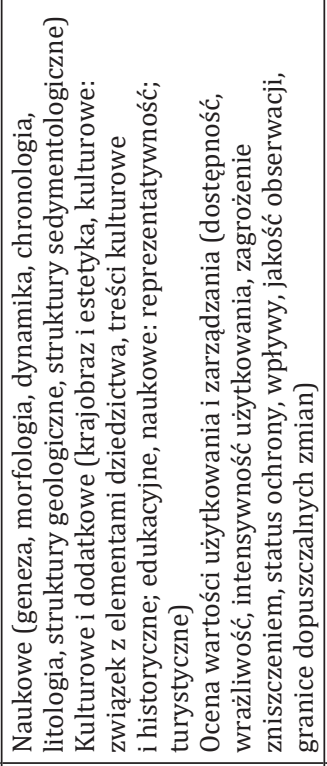 & 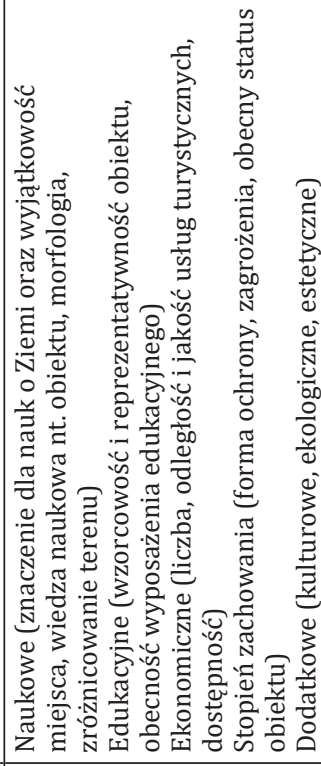 \\
\hline & 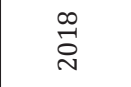 & $\underset{\sim}{\stackrel{\sigma}{\sim}}$ & $\underset{\sim}{\stackrel{\sim}{\sim}}$ & $\underset{\sim}{\stackrel{O}{S}}$ \\
\hline & 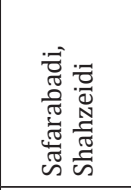 & 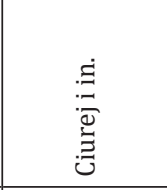 & 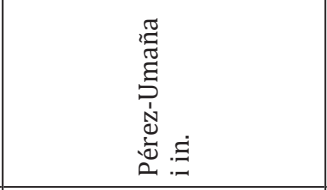 & 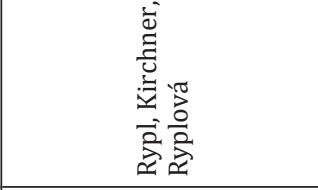 \\
\hline กี & గి & मे & 냉 & 占 \\
\hline
\end{tabular}




\begin{tabular}{|c|c|c|c|}
\hline 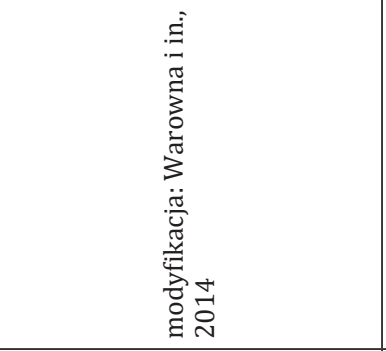 & 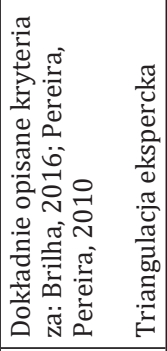 & 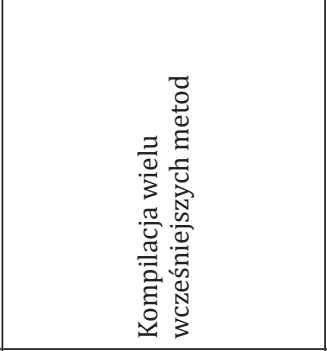 & 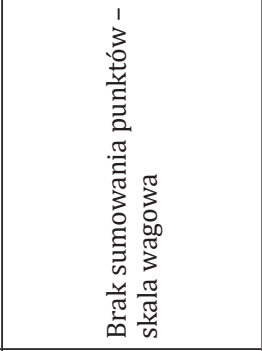 \\
\hline 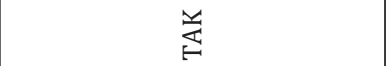 & 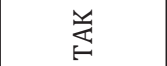 & 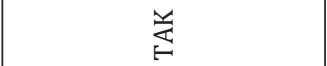 & $\frac{\omega}{z}$ \\
\hline$\grave{1}$ & $\begin{array}{l}\text { ?े } \\
\text { o }\end{array}$ & 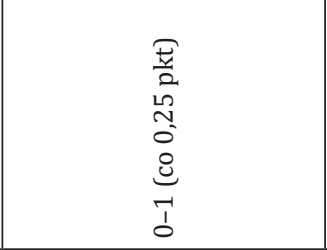 & 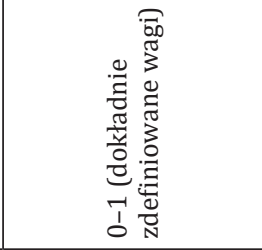 \\
\hline 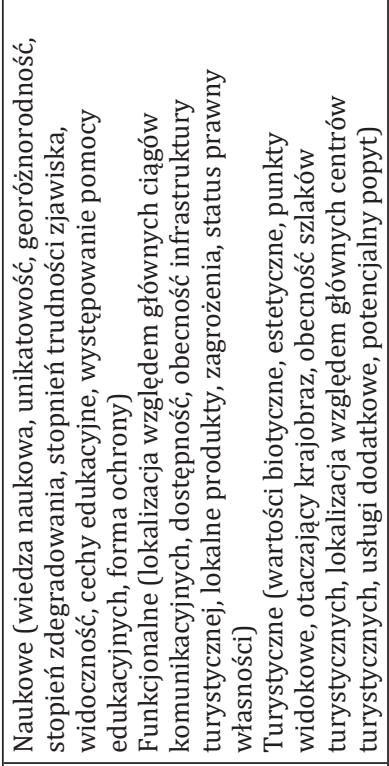 & 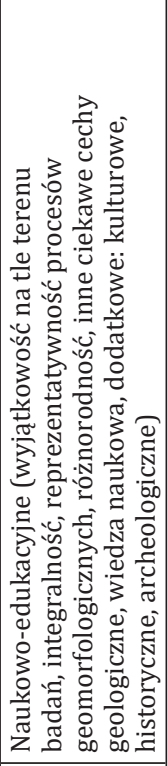 & 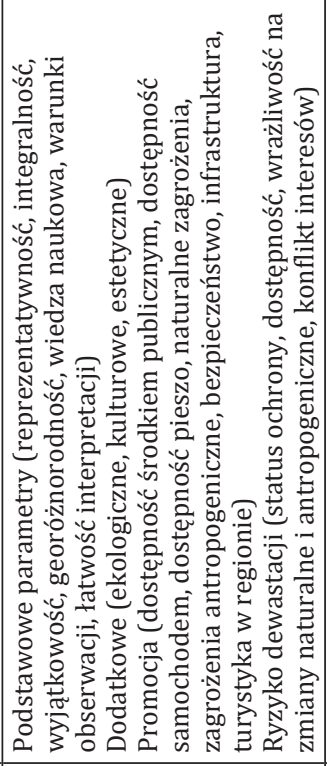 & 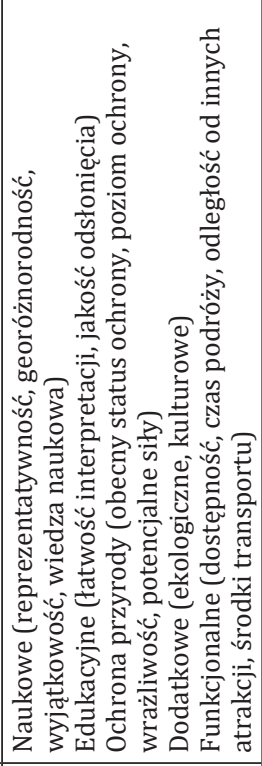 \\
\hline 定 & 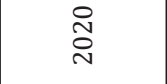 & 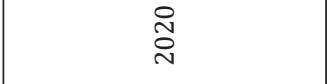 & స్ \\
\hline 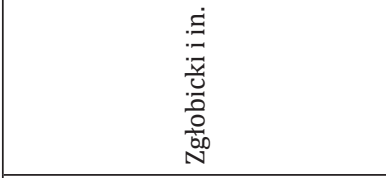 & 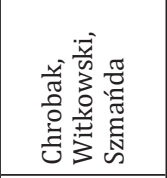 & 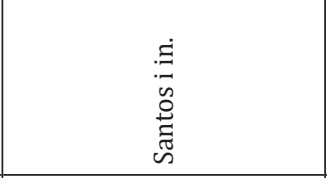 & 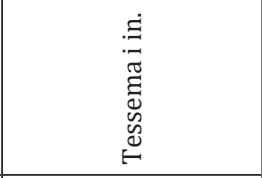 \\
\hline ถิ & $\stackrel{\infty}{\infty}$ & ฉิ & 8 \\
\hline
\end{tabular}


Ostateczny wskaźnik waloryzacji w większości metod tworzy suma poszczególnych kryteriów (Fassoulas i in., 2012; Kubalíková, Kirchner, 2016; Necheş, 2013; Pereira, Pereira, 2010; Rybár, 2010; Zouros, 2007) lub ich średnia arytmetyczna (Comănescu, Nedelea, Dobre, 2012; Niculiță, Mărgărint, 2018; Pralong, 2005; Reynard i in., 2007). Czasem ostateczny wskaźnik waloryzacji jest obliczany za pomocą średniej ważonej bądź dzięki nadaniu odpowiednich wag dla poszczególnych grup kryteriów (Chrobak, 2018; Coratza, Giusti, 2005; Coratza i in., 2011).

\section{WYBÓR GEOSTANOWISK DO WALORYZACJI}

Odpowiedni wybór, a także opis geostanowisk przeznaczonych do waloryzacji również jest istotny w metodyce. Wszystkie cytowane metody waloryzacji mają mniej bądź bardziej opisany sposób wyboru geostanowisk. Autorzy metod waloryzacji przy wyborze geostanowisk wykorzystują przede wszystkim przegląd literatury, prace terenowe, interpretacje map topograficznych, geologicznych i geomorfologicznych, ortofotomap, zdjęć satelitarnych oraz numerycznych modeli terenu, kartowanie geomorfologiczne, wykorzystanie wiedzy eksperckiej, interpretację źródeł historycznych czy przegląd publikacji turystycznych. Szczegółowy opis waloryzowanych geostanowisk pojawia się w cytowanej literaturze dość rzadko, mimo iż jest to bardzo istotny element wpływający na wartości przypisywanych punktów do poszczególnych kryteriów waloryzacji (Mucivuna i in., 2019).

\section{SKALA PUNKTOWA}

Założeniem każdej metody bonitacji punktowej, a zatem również i metod waloryzacji, jest odpowiednie zdefiniowanie skali punktowej w odniesieniu do wieku skał i procesów kształtujących dane geostanowisko, a także zagospodarowania jego bezpośredniego otoczenia. Mimo iż wiek skał i ogół procesów geologicznych odgrywają najważniejsze znaczenie w powstawaniu ciekawych obiektów przyrody nieożywionej, to w większości prac opisujących metody waloryzacji nie jest sprecyzowane, w jaki sposób zostały one wykorzystane w selekcji geostanowisk i ich ocenie jakościowej. Zagospodarowanie geostanowiska natomiast jest opisywane przede wszystkim w odniesieniu do jego bezpośredniego sąsiedztwa (infrastruktury turystycznej, wyposażenia w usługi hotelarskie, gastronomiczne i inne), a nie do skali oddziaływania samego geostanowiska, co pokazuje, że w większości metod waloryzacji nie jest zdefiniowana wielkość czy kompleksowość skali oddziaływania geostanowiska na jego otoczenie.

Podsumowując, przedstawione do tej pory w literaturze różne metody waloryzacji geostanowisk należą do jednej z pięciu grup, wg Mucivuna i in. (2019) są to:

- autorskie metody waloryzacji geostanowisk;

- metody wcześniej opisane w literaturze;

- metody wcześniej opisane w literaturze z późniejszymi zmianami;

- kompilacja różnych metod;

- metody bez ściśle zdefiniowanych kryteriów.

\section{PRZYKŁAD ZASTOSOWANIA RÓŻNYCH METOD WALORYZACJI}

Czasem podobne metody waloryzacji były stosowane w ocenie tych samych geostanowisk, ale przez to, że posiadały różnie zdefiniowane skale punktowe oraz kryteria 
oceny, wyniki też były bardzo odmienne lub często nieporównywalne, co bardzo dobrze zostało przedstawione na przykładzie słowackich geostanowisk: skalnego miasta Dreveník zbudowanego z trawertynów, gejzeru zlokalizowanego w miejscowości Herl'any oraz jaskini Domica (Štrba i in., 2014). Geostanowiska te zostały ocenione za pomocą sześciu metod waloryzacji (Baca, Schuster, 2011; Bruschi, Cendrero, Albertos, 2011; Fassoulas i in., 2012; Pereira, Pereira, Caetano Alves, 2007; Reynard i in., 2007; Rybár, 2010). Każda z tych metod dała odrębne wyniki waloryzacji, gdzie nawet jaskinia Domica, która otrzymała najwyższe oceny w czterech zastosowanych metodach, w pozostałych dwóch znalazła się na drugim miejscu, a gejzer w Herl'anach oceniony w większości zastosowanych metod na 2 i 3 miejscu, wg metody Pereiry, Pereiry i Caetano Alvesa (2007) znalazł się na pierwszym miejscu.

Podobne porównanie dwóch metod waloryzacji (Pereira, Pereira, 2010; Rybár, 2010) na przykładzie 45 geostanowisk zlokalizowanych na terenie polskiej części Podtatrza (Polska południowa) zostało przedstawione w pracy Chrobak (2016). Wyniki tego porównania dowodzą, iż waloryzowane obiekty, które nie są znane, są trudno dostępne i zostały opisane tylko w specjalistycznych publikacjach naukowych, otrzymały niskie wyniki waloryzacji wg obu zastosowanych metod. Natomiast obiekty, które zostały ocenione najwyżej, zdecydowanie różnią się w zależności od zastosowanej metody. Metoda wg Pereiry P. i Pereiry D. (2010) uwzględnia poza aspektami naukowymi również inne elementy, przez co najwyższe oceny otrzymały punkty widokowe, które zarówno pod kątem naukowym, jak i turystycznym oraz innymi są atrakcyjne. Metoda Rybára (2010) natomiast uwypukla przede wszystkim walory naukowe, przez co najwyżej ocenionymi geostanowiskami zostały ciekawe odsłonięcia skalne ze skamieniałościami, przełomowe odcinki rzek czy torfowiska (Chrobak, 2016).

Zatem biorąc pod uwagę złożoność metod waloryzacji i ich stopień subiektywności, właśnie skala punktowa i precyzyjność opisu poszczególnych kryteriów oceny powinny być tymi elementami, które zostaną w metodzie najlepiej zdefiniowane.

\section{UWAGI METODYCZNE DO WALORYZACJI GEOSTANOWISK}

Przedstawiona poniżej analiza SWOT przedstawia mocne i słabe strony oraz szanse i zagrożenia, jakie wynikają z zastosowania metod waloryzacji (tabela 2).

Tabela 2. Analiza SWOT stosowania metod waloryzacji opisanych w literaturze

\begin{tabular}{|c|c|}
\hline $\begin{array}{l}\text { Mocne strony: } \\
\text { - ocena ekspercka geostanowisk; } \\
\text { - wskazanie wartości naukowej geostanowisk; } \\
\text { - wyodrębnienie tych geostanowisk, które } \\
\text { z punktu widzenia nauki i edukacji są najbardziej } \\
\text { wartościowe }\end{array}$ & $\begin{array}{l}\text { Słabe strony: } \\
\text { - subiektywność w ocenie; } \\
\text { - trudności lub wręcz brak możliwości porównania } \\
\text { wyników uzyskanych z różnych metod; } \\
\text { - brak jednoznacznej definicji skali punktowej; } \\
\text { - ocena oparta wyłącznie na wiedzy i doświadczeniu } \\
\text { osoby oceniającej dane geostanowiska }\end{array}$ \\
\hline $\begin{array}{l}\text { Szanse: } \\
\text { - udostępnienie geostanowisk o najwyższych } \\
\text { wartościach waloryzacji; } \\
\text { - próba hierarchizacji geostanowisk; } \\
\text { - pokazanie możliwości udostępnienia } \\
\text { geostanowisk o najwyższych współczynnikach } \\
\text { waloryzacji naukowej }\end{array}$ & $\begin{array}{l}\text { Zagrożenia: } \\
\text { - zastosowanie różnych metod waloryzacji nie daje } \\
\text { podobnych wyników; } \\
\text { - ocena geostanowisk nie jest obiektywna, } \\
\text { szczególnie jeśli chodzi o kryteria naukowe; } \\
\text { - udostępnienie geostanowisk o najwyższych } \\
\text { walorach naukowych nie zawsze spotka się } \\
\text { z pozytywnym odbiorem tego miejsca przez } \\
\text { turystów }\end{array}$ \\
\hline
\end{tabular}


Największym problemem, jaki pojawia się przy waloryzacji geostanowisk, jest subiektywność oceny, która przede wszystkim zależy od wiedzy i doświadczenia eksperta, który ją przeprowadza. Aby zmniejszyć stopień subiektywności oceny, autorka zaproponowała następujące rozwiązanie. Waloryzację geostanowisk należy przeprowadzić według dwóch głównych grup kryteriów: naukowo-edukacyjnego (zawierającego też kryteria naukowe) oraz turystycznego. Pozostałe grupy kryteriów (dotyczące ochrony geostanowiska, estetyczności bądź aspektów ekonomicznych i kulturowych) mogą stać się częścią proponowanych grup lub mogą zostać pominięte, np. liczba turystów odwiedzająca dane geostanowisko stanowi o jego atrakcyjności turystycznej i dobrze przeprowadzonej promocji, a nie o jego wartości. Proponowane grupy mogą zawierać kompilację różnych kryteriów proponowanych przez innych autorów metod waloryzacji. Autorka dla oceny geostanowisk na terenie Podtatrza (terenów otaczających Tatry) zastosowała kompilację metod Pereiry P. i Pereiry D. (2010) oraz Fassoulassa i in. (2012). Skala punktowa, która jak już wspomniano jest bardzo istotnym elementem waloryzacji, została bardzo dokładnie zdefiniowana w zakresie 0-10, a zatem wartości punktowe opisane w metodzie Pereiry P. i Pereiry D. (2010) zostały 10-krotnie zwiększone.

Końcowy wskaźnik waloryzacji został obliczony przy pomocy średniej ważonej:

$$
\mathrm{WK}=0,7_{\mathrm{WNE}}+0,3_{\mathrm{WT}}
$$

gdzie: WNE - wartości naukowo-edukacyjne; WT - wartości turystyczne.

Stosowanie średniej ważonej w tym przypadku jest szczególnie istotne, ponieważ to wartości naukowo-edukacyjne stanowią o wartości geostanowiska i są niezmienne, natomiast na wartości turystyczne (tj. dostępność komunikacyjną, promocję, obecność różnorodnych usług) człowiek ma największy wpływ.

Dodatkowym zabiegiem nie stosowanym dotąd w ocenie geostanowisk było wzbogacenie waloryzacji o wydzielenie 4 grup geostanowisk o szczególnych, wysokich, średnich i niskich wartościach wskaźnika waloryzacji, obliczonych przy pomocy metody zaproponowanej przez J. Warszyńską (Warszyńska, 1970). Autorka proponuje, aby wartość końcowego wskaźnika waloryzacji została podzielona przez jego wartość maksymalną tak, aby wszystkie wartości mieściły się w przedziale od 0 do 1.

\section{METODA TRIANGULACJI (EKSPERCKA)}

Subiektywność w metodach waloryzacji nie odnosi się tylko do wyboru poszczególnych grup kryteriów i zdefiniowania skali punktowej, ale też do samej oceny poszczególnych geostanowisk. Jak w przypadku grupy kryteriów turystycznych odpowiednie zdefiniowanie skali punktowej wystarczy, aby ten stopień subiektywności zredukować, tak w przypadku grupy kryteriów naukowo-edukacyjnych może to być niewystarczające. Dlatego też w ocenie kryteriów naukowo-edukacyjnych warto zastosować metodę triangulacji (Denzin, 1970; Flick, 2011). Metoda triangulacji z definicji może być przeprowadzona na trzy sposoby. Pierwszy z nich to tzw. triangulacja ekspercka, która zakłada prowadzenie takich samych analiz przez kilku badaczy. Drugi sposób ma na celu rozwiązanie problemu badawczego za pomocą różnych metod. Trzeci sposób łączy natomiast różne rodzaje danych uzyskanych w różnych miejscach i odcinkach czasowych oraz przeprowadzonych na różnych populacjach. Metoda triangulacji pozwala podnieść 
jakość badań poprzez ich wieloaspektową analizę (Flick, 2011), w tym również badań w turystyce (Čuka, 2011).

W ocenie kryteriów edukacyjnych zastosowano triangulację ekspercką, gdzie poza autorem waloryzacji oceny poszczególnych geostanowisk podejmują się minimalnie 2 inne osoby, najlepiej, aby były to osoby, które znają oceniane geostanowiska oraz reprezentują różne dyscypliny naukowe bądź specjalizują się w różnych dziedzinach. Autorka przeprowadziła taką waloryzację ekspercką dla geostanowisk zlokalizowanych na Orawie. Oprócz niej waloryzacji tych samych obiektów, według tych samych kryteriów, dokonało trzech innych naukowców specjalizujących się w geologii, geomorfologii i geografii regionalnej. Poniższa tabela przedstawia wyniki tej waloryzacji. Najmniejsze różnice w ocenie geostanowisk dotyczyły odsłonięcia wielobarwnych plejstoceńskich piasków rzecznych w miejscowości Lipnica Wielka, utworów formacji pienińskiej w kamieniołomie Halečkova oraz odsłonięcia eoceńskiego fliszu łupkowo-piaskowcowego w miejscowości Huty (nr 57). Natomiast największe różnice w ocenie dotyczyły geostanowisk: Pucovské zlepence w miejscowości Pucov, Františkovej huty żelaza oraz Odsłonięcia lignitów w miejscowości Čimhová (tabela 3).

Tabela 3. Wyniki waloryzacji według oceny walorów edukacyjnych na Orawie

\begin{tabular}{|c|c|c|c|c|c|c|c|c|c|}
\hline \multirow{2}{*}{ Lp. } & \multirow{2}{*}{ Nazwa geostanowiska } & \multicolumn{5}{|c|}{$\begin{array}{c}\text { Wartości waloryzacji według kryteriów } \\
\text { edukacyjnych }\end{array}$} & \multirow{2}{*}{ 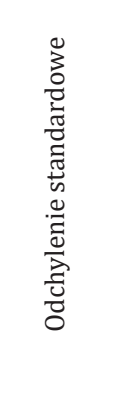 } & \multirow{2}{*}{ 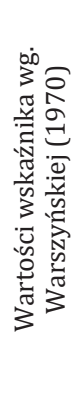 } & \multirow{2}{*}{ 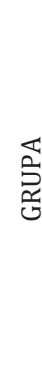 } \\
\hline & & 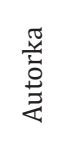 & 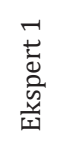 & $\begin{array}{l}N \\
\frac{n}{2} \\
\frac{0}{n} \\
\frac{x}{41}\end{array}$ & 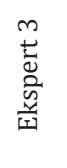 & 胥 & & & \\
\hline 1 & $\begin{array}{l}\text { Wapienna skałka } \\
\text { z Zamkiem Orawskim } \\
\text { nad rzeką Orawa (nr 61) }\end{array}$ & 57,5 & 37,5 & 56,6 & 64,2 & 53,95 & 9,94095 & 0,77 & I \\
\hline 2 & $\begin{array}{l}\text { Czerwone wapienie } \\
\text { jurajskie ze } \\
\text { skamieniałościami } \\
\text { w miejscowości Podbiel } \\
\text { (nr 63) }\end{array}$ & 56,7 & 32,6 & 45,8 & 60,9 & 49,00 & 10,9556 & 0,70 & I \\
\hline 3 & $\begin{array}{l}\text { Torfowisko Przybojec } \\
\text { w miejscowości Sucha } \\
\text { Hora (nr 70) }\end{array}$ & 47,6 & b.d. & 35,8 & 51,8 & 45,07 & 6,77315 & 0,64 & II \\
\hline 4 & $\begin{array}{l}\text { Pucovské zlepence } \\
\text { w miejscowości Pucov } \\
\text { (nr 58) }\end{array}$ & 54,2 & 25,8 & 42,5 & 56,7 & 44,80 & 12,2092 & 0,64 & II \\
\hline 5 & Jezioro Orawskie (nr 69) & 40 & 39,1 & 56,7 & 38,3 & 43,53 & 7,63033 & 0,62 & II \\
\hline 6 & $\begin{array}{l}\text { Ostrá skala i Tupá skala } \\
\text { koło miejscowości Wyżni } \\
\text { Kubin (nr 59) }\end{array}$ & 41,7 & 18,3 & 37,4 & 45,9 & 35,83 & 10,5549 & 0,51 & II \\
\hline 7 & $\begin{array}{l}\text { Biela Skala koło } \\
\text { miejscowości Podbiel } \\
\text { (nr 62) }\end{array}$ & 42,5 & 25,9 & 27,5 & 43,4 & 34,83 & 8,15088 & 0,50 & II \\
\hline
\end{tabular}




\begin{tabular}{|c|c|c|c|c|c|c|c|c|c|}
\hline 8 & $\begin{array}{l}\text { Odsłonięcie uwęglonych } \\
\text { szczątków roślin w iłach } \\
\text { neogeńskich w potoku } \\
\text { Lipnica (nr 72) }\end{array}$ & 35,1 & 41,7 & 12,5 & 29,2 & 29,63 & 10,8308 & 0,43 & III \\
\hline 9 & $\begin{array}{l}\text { Punkt widokowy na } \\
\text { Kotlinę Orawsko- } \\
\text { Nowotarską } \\
\text { w miejscowości Liesek } \\
\text { (nr 67) }\end{array}$ & 29,2 & 20 & 34,2 & 30 & 28,35 & 5,18146 & 0,40 & III \\
\hline 10 & $\begin{array}{l}\text { Odsłonięcie lignitów } \\
\text { w miejscowości Čimhová } \\
\text { (nr 68) }\end{array}$ & 27,5 & 10 & 42,5 & 27,5 & 26,88 & 3,06298 & 0,38 & III \\
\hline 11 & $\begin{array}{l}\text { Eoceński flisz } \\
\text { łupkowo-piaskowcowy } \\
\text { w miejscowości Huty } \\
\text { (nr 57) }\end{array}$ & 24,1 & 28,3 & 30,8 & 22,5 & 26,43 & 3,29649 & 0,38 & III \\
\hline 12 & $\begin{array}{l}\text { Odsłonięcie } \\
\text { wielobarwnych } \\
\text { plejstoceńskich } \\
\text { piasków rzecznych } \\
\text { w miejscowości Lipnica } \\
\text { Wielka (nr 71) } \\
\end{array}$ & 25,9 & 28,4 & 22,5 & 27,5 & 26,08 & 2,2499 & 0,37 & III \\
\hline 13 & $\begin{array}{l}\text { Františkova huta żelaza } \\
\text { (nr 64) }\end{array}$ & 22,5 & 5,8 & 40 & 25 & 23,33 & 12,1312 & 0,33 & III \\
\hline 14 & $\begin{array}{l}\text { Morskie i lądowe } \\
\text { skamieniałości jurajskie } \\
\text { w kamieniołomie } \\
\text { Halečkova koło } \\
\text { miejscowości Trstena } \\
\text { (nr 66) }\end{array}$ & 23,4 & 22,5 & 15,8 & 23,4 & 21,28 & 3,18228 & 0,30 & III \\
\hline 15 & $\begin{array}{l}\text { Odsłonięcie warstw } \\
\text { chochołowskich } \\
\text { fliszu podhalańskiego } \\
\text { w Orawicach (nr 65) }\end{array}$ & 17,5 & 28,4 & 20,8 & 17,5 & 21,05 & 4,45225 & 0,30 & III \\
\hline 16 & $\begin{array}{l}\text { Odsłonięcie skalne } \\
\text { Jasenová (nr 60) }\end{array}$ & 7,5 & b.d. & 15,8 & 8,3 & 10,53 & 3,73839 & 0,15 & IV \\
\hline
\end{tabular}

Źródło: Chrobak, 2018 r.

Wyniki tej waloryzacji eksperckiej jednoznacznie wykazały, że wiedza, doświadczenie oraz specjalizacja eksperta dokonującego oceny wywiera ogromny wpływ na ilość przypisywanych punktów. Na przykład według ocen geologów najwyższe wartości waloryzacji osiągnęły odsłonięcia skalne, które z kolei nie zostały docenione aż w taki sposób przez geomorfologów. Z drugiej strony, geomorfolodzy najwyżej w tej kategorii ocenili punkty widokowe oraz fragmenty dolin rzecznych, a według geografów regionalnych geostanowiskami o najwyższej wartości naukowo-edukacyjnej są obiekty, które już są znanymi punktami turystycznymi, często ze względu na ich wysoką wartość kulturową i historyczną, a przy tej okazji są one bardzo dobrze zagospodarowane turystycznie.

\section{PodsumoWANIE}

Podsumowując, przedstawiona $\mathrm{w}$ niniejszym artykule analiza 60 metod waloryzacji pozwoliła na wytypowanie najważniejszych grup kryteriów służących ocenie 
geostanowisk, którymi są kryteria naukowe, turystyczne (potencjał użytkowania) oraz dodatkowe (w tym kulturowe i estetyczne).

Sama metodyka waloryzacji geostanowisk jest wciąż rzeczą problematyczną, zawierającą wiele aspektów wymagających dopracowania, z których najważniejszy jest stopień subiektywności. Analiza metod waloryzacyjnych wykazała, że 23 metody nie mają ściśle zdefiniowanych kryteriów i skali punktowej, co sprawia, że ocena geostanowisk według tych metod zależy wyłącznie od wiedzy i doświadczenia naukowca prowadzącego waloryzację.

Aspektami, które również wymagają udoskonalenia i ujednolicenia, są grupy kryteriów, jakie powinny być użyte w waloryzacji oraz skala punktowa, jaką należy zastosować i ją odpowiednio zdefiniować. Ujednolicenie tych aspektów umożliwi porównywanie wyników waloryzacji geostanowisk.

Mimo iż stworzenie optymalnej i obiektywnej metody waloryzacji geostanowisk na dzień dzisiejszy jest raczej niemożliwe, to zdaniem autorki zastosowanie metody triangulacji eksperckiej pozwoli zmniejszyć ich stopień subiektywności.

\section{Podziękowania}

Autorka niniejszego artykułu dziękuje recenzentom za cenne i wnikliwe uwagi przesłane do niniejszego artykułu.

Badania zostały sfinansowane ze środków na badania statutowe Uniwersytetu Pedagogicznego w Krakowie nr BN.610-408/PBU/2020 oraz BN.610-116/PBU/2020.

\section{Literatura}

\section{References}

Alba, C.D. (2016). Geomorphosites with touristic value in the central - southern part of the Parâng Mountains. Forum Geografic, 15(1), 109-115. doi: 10.5775/fg.2016.054.i

Alexandrowicz, Z. (2004). Important geosites of Poland in relation to the ecological network Natura 2000. Polish Geological Institute Special Papers, 13, 41-48.

Alexandrowicz, Z., Alexandrowicz, S.W. (2002). Geoturystyka a promocja dziedzictwa geologicznego. W: J. Partyka (red.), Użytkowanie Turystyczne Parków Narodowych ruch turystyczny - zagospodarowanie - konflikty - zagrożenia. Ojców: Instytut Ochrony Przyrody PAN, Ojcowski Park Narodowy, 91-97.

Alexandrowicz, Z., Kućmierz, A., Urban, J., Otęska-Budzyń, J. (1992). Waloryzacja przyrody nieożywionej obszarów i obiektów chronionych w Polsce. Warszawa: Wydawnictwo Państwowego Instytutu Geologicznego.

Artugyan, L. (2017). Geomorphosites Assessment in Karst Terrains: Anina Karst Region (Banat Mountains, Romania). Geoheritage, 9(2), 153-162. doi: 10.1007/s12371-016-0188-x

Avanzini, M., Carton, A., Seppi, R., Tomasoni, R. (2005). Geomorphosites in Trentino: A first census. Alpine and Mediterranean Quaternary, 18(1), 63-78.

Baca, I., Schuster, E. (2011). Listing, evaluation and touristic utilisation of geosites containing archaeological artefacts. Case study: Ciceu ridge (Bistrita-Nasaud Country, Romania). Revista Geografica Academica, 5(1), 5-20.

Bartuś, T. (2015). Geotourist maps of the Sudetic Geostrada Trail as a new form of popularization of geotourism in the Sudety Mts. Geotourism, 40-41(1-2), 3-18. doi: 10.7494/geotour.2015.40-41.3

Bollati, I., Pelfini, M., Pellegrini, L. (2012). A geomorphosites selection method for educational purposes: A case study in Trebbia Valley (Emilia Romagna, Italy). Geografia Fisica e Dinamica Quaternaria, 35, 23-35. doi: 10.4461/GFDQ.2012.35.3

Bollati, I., Smiraglia, C., Pelfini, M. (2013). Assessment and selection of geomorphosites and trails in the Miage Glacier area (Western Italian Alps). Environmental Management, 51, 951-967. doi: $10.1007 / \mathrm{s} 00267-012-9995-2$ 
Bosson, J.B., Reynard, E. (2012). Geomorphological heritage, conservation and promotion in high-alpine protected areas. Eco.Mont, 4(1), 13-22. doi: 10.1553/eco.mont-4-1s13

Bouzekraoui, H., Barakat, A., Touhami, F., Mouaddine, A., El Youssi, M. (2018). Inventory and assessment of geomorphosites for geotourism development: A case study of Aït Bou Oulli valley (Central High-Atlas, Morocco). Area, 50(3), 331-343. doi: 10.1111/area.12380

Brilha, J. (2016). Inventory and quantitative assessment of geosites and geodiversity sites: a review. Geoheritage, 8(2), 119-134. doi: 10.1007/s12371-014-0139-3

Bruschi, V.M., Cendrero, A. (2005). Geosite evaluation; can we measure intangible values? Il Quaternario, 18(1), 293-306.

Bruschi, V. M., Cendrero, A., Albertos, J.A.C. (2011). A statistical approach to the validation and optimisation of geoheritage assessment procedures. Geoheritage, 3(3), 131-149. doi: 10.1007/ s12371-011-0038-9

Chrobak, A. (2016). Valorisation and categorisation of the geosites in the Podtatrze area (Southern Poland). Geotourism, 46-47(3-4), 3-26. doi: 10.7494/geotour.2016.46-47.3

Chrobak, A. (2018). Analiza i ocena potencjału geoturystycznego Podtatrza [praca doktorska]. Kraków: Uniwersytet Pedagogiczny w Krakowie, Instytut Geografii.

Chrobak, A., Cebulski, J. (2014). Landslides in the Polish Carpathians as the potential educational geosites. Current Issues of Tourism Research, 4(1), 38-49.

Chrobak, A., Witkowski, K., Szmańda, J. (2020). Assessment of the educational values of geomorphosites based on the expert method, case study: The Białka and Skawa Rivers, the Polish Carpathians. Quaestiones Geographicae, 39(1), 45-57. doi: 10.2478/quageo-2020-0004

Ciurej, A., Chrobak, A., Wolska, A., Kowalik, S. (2019). Valorization of geosites in Western Tatra Mountains (Chochołowska Valley) with focus on tourist activity of people with physical disabilities. Prace Komisji Geografii Przemysłu Polskiego Towarzystwa Geograficznego [Studies of the Industrial Geography Commission of the Polish Geographical Society], 33(3), 148-158. doi: $10.24917 / 20801653.333 .10$

Clivaz, M., Reynard, E. (2018). How to integrate invisible geomorphosites in an inventory: a case study in the Rhone River Valley (Switzerland). Geoheritage, 10(4), 527-541. doi: 10.1007/ s12371-017-0222-7

Cocean, G., Cocean, P. (2017). An Assessment of Gorges for Purposes of Identifying Geomorphosites of Geotourism Value in the Apuseni Mountains (Romania). Geoheritage, 9(1), 71-81. doi: 10.1007/s12371-016-0180-5

Comănescu, L., Dobre, R. (2009). Inventorying, evaluating and tourism valuating the geomorphosites from the central sector of the Ceahlău national park. GeoJournal of Tourism and Geosites, 3(1), 86-96.

Comănescu, L., Nedelea, A. (2010). Analysis of some representative geomorphosites in the Bucegi Mountains: Between scientific evaluation and tourist perception. Area, 42(4), 406-416. doi: 10.1111/j.1475-4762.2010.00937.x

Comănescu, L., Nedelea, A., Dobre, R. (2009). Inventorying and evaluation of geomorphosites in the Bucegi Mountains. Forum Geografic, 8(8), 38-43.

Comănescu, L., Nedelea, A., Dobre, R. (2012). The Evaluation of geomorphosites from the Ponoare protected area. Forum Geografic, 11(1), 54-61. doi: 10.5775/fg.2067-4635.2012.037.i

Comănescu, L., Nedelea, A., Dobre, R. (2011). Evaluation of geomorphosites in Vistea Valley (Fagaras Mountains-Carpathians, Romania). International Journal of Physical Sciences, 6(5), 1161-1168. doi: 10.5897/IJPS10.384

Comănescu, L., Nedelea, A., Stănoiu, G. (2017). Geomorphosites and geotourism in Bucharest city center (Romania). Quaestiones Geographicae, 36(3), 51-61. doi: 10.1515/quageo-2017-0029

Coratza, P., Bruschi, V.M., Piacentini, D., Saliba, D., Soldati, M. (2011). Recognition and assessment of geomorphosites in Malta at the Il-Majjistral Nature and History Park. Geoheritage, 3(3), 175-185. doi: 10.1007/s12371-011-0034-0

Coratza, P., Giusti, C. (2005). Methodological proposal for the assessment of the scientific quality of geomorphosites. Il Quaternario, 18(1), 305-311.

Costa-Casais, M., Alves, M.I.C., Blanco-Chao, R. (2015). Assessment and management of the geomorphological heritage of Monte Pindo (NW Spain): A landscape as a symbol of identity. Sustainability, 7(6), 7049-7085. doi: 10.3390/su7067049 
Costa-Casais, M., Caetano Alves, M.I. (2013). Geological Heritage at Risk in NW Spain. Quaternary Deposits and Landforms of "Southern Coast" (Baiona-A Garda). Geoheritage, 5(4), 227-248. doi: 10.1007/s12371-013-0083-7

Costa, F.L. (2011). Volcanic Geomorphosites Assessment of the Last Eruption, on April To May 1995, Within the Natural Park of Fogo Island, Cape Verde. GeoJournal of Tourism and Geosites., 8(2), 167-177.

Costamagna, A. (2005). A geomorphosites inventory in central Piemonte (NW Italy): First results. Il Quaternario. Italian Journal of Quaternary Sciences, 18(1), 23-37.

Čuka, P. (2011). Základy teórie, metodológie a regionalizácie cestovného ruchu. Vydavatel'stvo Prešovskej Univerzity, Prešov 93.

De Waele, J., Di Gregorio, F., Pala, A. (2005). Karst Geomorphosites of Monte Albo (north-east Sardinia). Il Quaternario. Italian Journal of Quaternary Sciences, 18(1), 143-151.

Del Monte, M., Fredi, P., Pica, A., Vergari, F. (2013). Geosites within Rome City center (Italy): A mixture of cultural and geomorphological heritage. Geografia Fisica e Dinamica Quaternaria, 36, 241-257. doi: 10.4461/GFDQ.2013.36.20

Denzin, N.K. (1970). The Research Act. Chicago: Aldine.

Dmytrowski, P., Kicińska, A. (2011). Waloryzacja geoturystyczna obiektów przyrody nieożywionej i jej znaczenie w perspektywie rozwoju geoparków. Problemy Ekologii Krajobrazu, 29, $11-20$.

Dóniz-Páez, J., Becerra-Ramírez, R., González-Cárdenas, E., Guillen-Martin, C., Escobar-Lahoz, E. (2011). Geomorphosite and geotourism in volcanic landscape: the example of La Corona Del Lajial Cinder Cone (El Hierro, Canary Islands, Spain). GeoJournal of Tourism and Geosites, $8(2), 185-197$.

Erhartič, B. (2010). Geomorphosite assessment. Acta Geographica Slovenica, 50(2), 295-319. doi: $10.3986 /$ ags50206

Fassoulas, C., Mouriki, D., Dimitriou-Nikolakis, P., Iliopoulos, G. (2012). Quantitative Assessment of Geotopes as an Effective Tool for Geoheritage Management. Geoheritage, 4(3), 177-193. doi: 10.1007/s12371-011-0046-9

Fattori, C., Mancinella, D. (2010). La conservazione del patrimonio geologico del Lazio. Materiali, modelli, esperienze. Roma: Edizioni ARP-Agenzia Regionale Parchi.

Feuillet, T., Sourp, E. (2011). Geomorphological heritage of the Pyrenees National Park (France): Assessment, clustering, and promotion of geomorphosites. Geoheritage, 3(3), 151-162. doi: 10.1007/s12371-010-0020-y

Flick, U. (2011). Jakość w badaniach jakościowych. Warszawa: Wydawnictwo Naukowe PWN.

Geremia, F., Massoli-Novelli, R. (2005). Coastal geomorphosites of the Isles of Lipari and Stromboli (Aeolian islands, Italy): New potential for geo-tourism. Il Quaternario. Italian Journal of Quaternary Sciences, 18(1), 233-244.

Golonka, J., Krobicki, M. (2007). The Dunajec River rafting - one of the most interesting geotouristic excursions in the future trans-border PIENINY Geopark. Geoturystyka, 10(3), 29-44.

Golonka, J., Krobicki, M., Miśkiewicz, K., Słomka, T., Waśkowska, A., Doktor, M. (2013). Geopark "Beskid Śląsko-Morawsko-Żywiecki" - najstarsze utwory Karpat fliszowych. Przegląd Geologiczny, 61(5), 277-285.

Hose, T.A. (1995). Selling the story of Britain's stone. Environ Interpretation, 10(2), 16-17.

Hose, T.A. (2000). European geotourism - geological interpretation and geoconservation promotion for tourists. W: D. Barretino, W.A.P. Wimbledon, E. Gallego (red.), Geological Heritage: Its Conservation and Management. Madrid: Instituto Tecnologico GeoMinero de Espana, 127-146.

Hose, T.A. (2008). Towards a history of geotourism: definitions, antecedents and the future. Geological Society.Special Publications, 300(1), 37-60. doi: 10.1144/SP300.5

Hose, T.A. (2011). The genesis of geotourism and its management implications. W: T. Słomka (red.), Geotourism: a variety of aspects. Kraków: Akademia Górniczo-Hutnicza, 23-38.

Ilinca, V., Comănescu, L. (2011). Aspects concerning some of the geomorphosites with tourist valur from Vâlcea County (Romania). GeoJournal of Tourism and Geosites, 7(1), 22-32.

Joyce, E.B. (2006). Geomorphological sites and the new geotourism in Australia. Geological Society of Australia. Pozyskano z: http://earthsci.unimelb.edu.au/Joyce/heritage/geotourisminaustralia.html 
Jurj, M.A. (2016). The geomorphosites of Roşia Montană. Geographia Napocensis, 10(1), 95-101.

Knapik, R., Migoń, P., Szuszkiewicz, A., Aleksandrowski, P. (2011). Geopark Karkonosze - georóżnorodność i geoturystyka. Przeglad Geologiczny, 59(4), 311-322.

Koźma, J. (2008). Opracowanie zasad identyfikacji i waloryzacji geotopów dla potrzeb sporządzania dokumentacji projektowych geoparków w Polsce z zastosowaniem systemów GPS i GIS. Warszawa, Wrocław: Archiwum Państwowego Instytutu Geologicznego.

Krobicki, M., Golonka, J. (2008). Podhale Palaeogene Flysch as geotouristic attractive region first look to its unique geological values. Geoturystyka, 13(2), 25-44.

Krzeszowska, E. (2013). Selected geotourist attractions of Death Valley, USA. Geotourism, 3233(1-2), 59-68.

Kubalíková, L. (2013). Geomorphosite assessment for geotourism purposes. Czech Journal of Tourism, 2(2), 80-104. doi: 10.2478/cjot-2013-0005

Kubalíková, L., Kirchner, K. (2016). Geosite and geomorphosite assessment as a tool for geoconservation and geotourism purposes: a case study from Vizovická vrchovina Highland (Eastern part of the Czech Republic). Geoheritage, 8(1), 5-14. doi: 10.1007/s12371-0150143-2

Kurek, W. (2008). Turystyka. Warszawa: Wydawnictwo Naukowe PWN.

Maghsoudi, M., Rahmati, M. (2018). Geomorphosites assessment of Lorestan Province in Iran by comparing of zouros and Comanescu's methods (case study: Poldokhtar area, Iran). Geojournal of Tourism and Geosites, 21(1), 226-238.

Mauerhofer, L., Reynard, E., Asrat, A., Hurni, H. (2018). Contribution of a geomorphosite inventory to the geoheritage knowledge in developing countries: the case of the Simien Mountains National Park, Ethiopia. Geoheritage, 10(4), 559-574. doi: 10.1007/s12371-017-0234-3

Mucivuna, V.C., Reynard, E., Garcia, M. da G.M. (2019). Geomorphosites assessment methods: comparative analysis and typology. Geoheritage, 11, 1799-1815. doi: 10.1007/s12371-01900394-X

Neches, I. (2013). From geomorphosite evaluation to geotourism interpretation. Case study: The sphinx of Romania's Southern Carpathians. Geojournal of Tourism and Geosites, 12(2), $145-162$.

Nedelea, A., Comănescu, L., Marin, M. (2010). Petrographical relief on the southern slope of the Făgăraș Mountains (the Argeș Basin, Romania) - premiss for identification of geomorphosites. GeoJournal of Tourism and Geosites, 5(1), 33-43.

Newsome, D., Dowling, R.K. (2010). Geotourism. The tourism of Geology and Landscape. Oxford: Goodfellow Publishers Limited. doi: 10.23912/978-1-906884-09-3-21

Niculiță, M., Mărgărint, M.C. (2018). Landslides and fortified settlements as valuable cultural geomorphosites and geoheritage sites in the Moldavian Plateau, North-Eastern Romania. Geoheritage, 10(4), 613-634. doi: 10.1007/s12371-017-0261-0

Ólafsdóttir, R. (2019). Geotourism. Geosciences, 9, 48-55.

Orrù, P., Panizza, V., Ulzega, A. (2005). Submerged Geomorphosites in the marine protected areas of Sardinia (Italy): Assessment and improvemen. Il Quaternario. Italian Journal of Quaternary Sciences, 18(1), 167-174.

Panizza, M. (2001). Geomorphosites: Concepts, methods and examples of geomorphological survey. Chinese Science Bulletin, 46, 4-5.

Panizza, V., Mennella, M. (2007). Assessing geomorphosites used for rock climbing: the example of Monteleone Rocca Doria (Sardinia, Italy). Geographica Helvetica, 62(3), 181-191.

Pellitero, R., González-Amuchastegui, M.J., Ruiz-Flaño, P., Serrano, E. (2011). Geodiversity and geomorphosite assessment applied to a natural protect area: the Ebro and Rudron gorges natural park (Spain). Geoheritage, 3(3), 163-174. doi: 10.1007/s12371-010- 0022-9

Pereira, P., Pereira, D. (2010). Methodological guidelines for geomorphosite assessment. Géomorphologie: Relief, Processus, Environnement, 16(2), 215-222. doi: 10.4000/geomorphologie.7942

Pereira, P., Pereira, D., Caetano Alves, M.I. (2007). Geomorphosite assessment in Montesinho Natural Park (Portugal). Geographica Helvetica, 62(3), 159-168. doi: 10.5194/gh-62-1592007 
Pérez-Umaña, D., Quesada-Román, A., De Jesús Rojas, J.C., Zamorano-Orozco, J.J., Dóniz-Páez, J., Becerra-Ramírez, R. (2019). Comparative analysis of geomorphosites in volcanoes of Costa Rica, Mexico, and Spain. Geoheritage, 11(2), 545-559. doi: 10.1007/s12371-018-0313-0

Pica, A., Luberti, G.M., Vergari, F., Fredi, P., Del Monte, M. (2017). Contribution for an Urban Geomorphoheritage Assessment Method: Proposal from Three Geomorphosites in Rome (Italy). Quaestiones Geographicae, 36(3), 21-36. doi: 10.1515/quageo-2017-0030

Pica, A., Vergari, F., Fredi, P., Del Monte, M. (2015). The Aeterna Urbs Geomorphological Heritage (Rome, Italy). Geoheritage, 8(1), 1-12. doi: 10.1007/s12371-015-0150-3

Pralong, J.P. (2005). A method for assessing tourist potential and use of geomorphological sites. Géomorphologie: Relief, Processus, Environnement, 11(3), 189-196. doi: 10.4000/geomorphologie.350

Reynard, E. (2004). Geosite. W: Goudie, A. (red.) Encyclopedia of Geomorphology, Taylor\&Francis. Routledge, 440.

Reynard, E., Brilha, J. (2018). Geoheritage: assessment, protection, and management. Amsterdam: Elselvier.

Reynard, E., Coratza, P. (2013). Scientific research on geomorphosites. A review of the activities of the IAG working group on geomorphosites over the last twelve years. Geografia Fisica $e$ Dinamica Quaternaria, 36(1), 159-168. doi: 0.4461/GFDQ.2013.36.13

Reynard, E., Coratza, P., Hobléa, F. (2016). Current Research on Geomorphosites. Geoheritage, 8(1), 1-3. doi: 10.1007/s12371-016-0174-3

Reynard, E., Fontana, G., Kozlik, L., Scapozza, C. (2007). A method for assessing "scientific" and "additional values" of geomorphosites. Geographica Helvetica, 62(3), 148-158. doi: 10.5194/gh-62-148-2007

Reynard, E., Panizza, M. (2005). Geomorphosites: definition, assessment and mapping. Géomorphologie: Relief, Processus, Environnement, 11(3), 177-180. doi: 10.4000/geomorphologie.337

Reynard, E., Perret, A., Bussard, J., Grangier, L., Martin, S. (2016). Integrated Approach for the Inventory and Management of Geomorphological Heritage at the Regional Scale. Geoheritage, 8(1), 43-60. doi: 10.1007/s12371-015-0153-0

Reynard, E., Pica, A., Coratza, P. (2017). Urban geomorphological heritage. An overview. Quaestiones Geographicae, 36(3), 7-20. doi: 10.1515/quageo-2017-0022

Rodrigues, M.L., Fonseca, A. (2010). Geoheritage assessment based on large-scale geomorphological mapping: contributes from a Portuguese limestone massif example. Géomorphologie: Relief, Processus, Environnement, 16(2), 189-198. doi: 10.4000/geomorphologie.7924

Rybár, P. (2010). Assessment of attractiveness (value) of geotouristic objects. Acta Geoturistica, $1(2), 13-21$.

Rypl, J., Kirchner, K., Ryplová, R. (2019). Contribution to the assessment of geomorphosites in the Czech Republic (a case study of the north-eastern part of the Novohradské Mountains). Geoheritage, 11(2), 427-439. doi: 10.1007/s12371-018-0293-0

Safarabadi, A., Shahzeidi, S.S. (2018). Tourism silence in geomorphosites: a case study of Ali-Sadr cave (Hamadan, Iran). Geojournal of Tourism and Geosites, 21(1), 49-60.

Sansò, P., Margiotta, S., Mastronuzzi, G., Vitale, A. (2015). The geological heritage of Salento Leccese area (Apulia, southern Italy). Geoheritage, 7(1), 85-101. doi: 10.1007/s12371-0130093-5

Santos, D.S., Mansur, K.L., Seoane, J.C.S., Mucivuna, V.C., Reynard, E. (2020). Methodological proposal for the inventory and assessment of geomorphosites: An integrated approach focused on territorial management and geoconservation. Environmental Management, 66(3), 476497. doi: $10.1007 /$ s00267-020-01324-2

Serrano, E., González-Trueba, J.J. (2005). Assessment of geomorphosites in natural protected areas: the Picos de Europa National Park (Spain). Géomorphologie : Relief, Processus, Environnement, 11(3), 197-208. doi: 10.4000/geomorphologie.364

Słomka, T., Kicińska-Świderska, A. (2004). Geoturystyka - podstawowe pojęcia. Geoturystyka, 1(1), 5-7.

Štrba, L., Rybár, P., Baláž, B., Molokáč, M., Hvizdák, L., Kršák, B., ... Ferenčíková, J. (2014). Geosite assessments: comparison of methods and results. Current Issues in Tourism, 18(5), 496-510. doi: $10.1080 / 13683500.2014 .882885$ 
Tessema, G.A., van der Borg, J., Minale, A.S., Van Rompaey, A., Adgo, E., Nyssen, J., ... Poesen, J. (2021). Inventory and assessment of geosites for geotourism development in the Eastern and Southeastern Lake Tana Region, Ethiopia. Geoheritage, 13(43). doi: 10.1007/s12371021-00560-0

Vdovets, M.S., Silantiev, V.V., Mozzherin, V.V. (2010). A national geopark in the Republic of Tatarstan (Russia): A feasibility study. Geoheritage, 2(1), 25-37. doi: 10.1007/s12371-0100010-0

Wang, G. (2015). Geoheritage Features in Xi'an, China: Cuihua Rock Avalanche Likely Originating from an Ancient Earthquake. Geoheritage, 7(3), 285-297. doi: 10.1007/s12371-014-0132-x

Warowna, J., Zgłobicki, W., Gajek, G., Telecka, M., Kołodyńska-Gawrysiak, R., Zieliński, P. (2014). Geomorphosite assessment in the proposed geopark Vistula River gap (E Poland). Quaestiones Geographicae, 33(3), 173-180. doi: 10.2478/quageo-2014-0040

Warszyńska, J. (1970). Waloryzacja miejscowości z punktu widzenia atrakcyjności turystycznej (zarys metody). Zeszyty Naukowe Uniwersytetu Jagiellońskiego. Prace Geograficzne (27), 103-114.

Zgłobicki, W., Poesen, J., Cohen, M., Del Monte, M., García-Ruiz, J.M., Ionita, I., ... Vergari, F. (2019). The potential of permanent gullies in Europe as geomorphosites. Geoheritage, 11(2), 217239. doi: 10.1007/s12371-017-0252-1

Zouros, N.C. (2007). Geomorphosite assessment and management in protected areas of Greece Case study of the Lesvos Island - coastal geomorphosites. Geographica Helvetica, 62(3), 169-180. doi: 10.5194/gh-62-169-2007

Anna Chrobak, dr, Uniwersytet Pedagogiczny w Krakowie, Instytut Geografii, Katedra Geologii. Prowadzi badania w następujących dziedzinach: 1) geografia fizyczna, zwłaszcza geomorfologia (procesy masowe osuwiska); 2) analiza georóżnorodności wybranych obszarów w Europie; 3) geoturystyka - inwentaryzacja i ocena ilościowa geostanowisk oraz 4) preferencje turystów.

Anna Chrobak, PhD, Pedagogical University of Krakow, Institute of Geography, Department of Geology. Research is conducted in the following fields: 1) physical geography, especially geomorphology (mass processes - landslides);2) geodiversity analysis of selected areas in Europe; 3) geotourism - inventory and quantitative assessment of geosites and 4) (geo)tourists preferences.

ORCID: https://orcid.org/0000-0003-3124-8853

\section{Adres/address:}

Uniwersytet Pedagogiczny im. KEN w Krakowie

Instytut Geografii, Katedra Geologii

ul. Podchorążych 2

30-084 Kraków

e-mail: anna.chrobak@up.krakow.pl 